\title{
Community-Based Coral Reef Rehabilitation in a Changing Climate: Lessons Learned from Hurricanes, Extreme Rainfall, and Changing Land Use Impacts
}

\author{
Edwin A. Hernández-Delgado ${ }^{1,2,3}{ }^{*}$, Alex E. Mercado-Molina 2,3 , Pedro J. Alejandro-Camis ${ }^{3}$, \\ Frances Candelas-Sánchez ${ }^{3}$, Jaime S. Fonseca-Miranda'2,3, Carmen M. González-Ramos1,2,3, \\ Roger Guzmán-Rodríguez ${ }^{3}$, Pascal Mège ${ }^{2}$, Alfredo A. Montañez-Acuñaa 1,2,3, \\ Iván Olivo Maldonado3 ${ }^{3}$ Abimarie Otaño-Cruz ${ }^{1,3,4}$, Samuel E. Suleimán-Ramos ${ }^{3}$ \\ ${ }^{1}$ Center for Applied Tropical Ecology and Conservation, Coral Reef Research Group, University of Puerto Rico, \\ San Juan, Puerto Rico \\ ${ }^{2}$ Department of Biology, University of Puerto Rico, San Juan, Puerto Rico \\ ${ }^{3}$ Sociedad Ambiente Marino, San Juan, Puerto Rico \\ ${ }^{4}$ Department of Environmental Sciences, University of Puerto Rico, San Juan, Puerto Rico \\ Email: ${ }^{*}$ edwin.hernandezdelgado@gmail.com
}

Received 6 September 2014; revised 6 October 2014; accepted 11 October 2014

Copyright $@ 2014$ by authors and Scientific Research Publishing Inc.

This work is licensed under the Creative Commons Attribution International License (CC BY). http://creativecommons.org/licenses/by/4.0/

(c) (i) Open Access

\section{Abstract}

Coral reefs have largely declined across multiple spatial scales due to a combination of local-scale anthropogenic impacts, and due to regional-global climate change. This has resulted in a significant loss of entire coral functional groups, including western Atlantic Staghorn coral (Acropora cervicornis) biotopes, and in a net decline of coral reef ecosystem resilience, ecological functions, services and benefits. Low-tech coral farming has become one of the most important tools to help restore depleted coral reefs across the Wider Caribbean Region. We tested a community-based, low-tech coral farming approach in Culebra Island, Puerto Rico, aimed at adapting to climate change-related impacts through a two-year project to propagate $A$. cervicornis under two contrasting fishing management conditions, in coastal areas experimenting significant land use changes. Extreme rainfall events and recurrent tropical storms and hurricanes had major site- and method-specific impacts on project outcome, particularly in areas adjacent to deforested lands and subjected to recurrent impacts from land-based source pollution (LBSP) and runoff. Overall, coral survival rate in "A frame" units improved from 73\% during 2011-2012 to 81\% during 2012-2013. Coral survival rate improved to $97 \%$ in horizontal line nurseries (HLN) incorporated

\footnotetext{
${ }^{*}$ Corresponding author.
}

How to cite this paper: Hernández-Delgado, E.A., et al. (2014) Community-Based Coral Reef Rehabilitation in a Changing Climate: Lessons Learned from Hurricanes, Extreme Rainfall, and Changing Land Use Impacts. Open Journal of Ecology, 4, 918-944. http://dx.doi.org/10.4236/oje.2014.414077 
during 2012-2013. Percent tissue cover ranged from $86 \%$ to $91 \%$ in "A frames", but reached $98 \%$ in HLN. Mean coral skeletal extension was $27 \mathrm{~cm} / \mathrm{y}$ in "A frames" and $40 \mathrm{~cm} / \mathrm{y}$ in HLN. These growth rates were up to $545 \%$ to $857 \%$ faster than previous reports from coral farms from other parts of the Caribbean, and up to $438 \%$ faster than wild colonies. Branch production and branchiness index (no. harvestable branches $>6 \mathrm{~cm}$ ) increased by several orders of magnitude in comparison to the original colonies at the beginning of the project. Coral mortality was associated to hurricane physical impacts and sediment-laden runoff impacts associated to extreme rainfall and deforestation of adjacent lands. This raises a challenging question regarding the impact of chronic high sea surface temperature (SST), in combination with recurrent high nutrient pulses, in fostering increased coral growth at the expense of coral physiological conditions which may compromise corals resistance to disturbance. Achieving successful local management of reefs and adjacent lands is vital to maintain the sustained net production in coral farms and of reef structure, and the provision of the important ecosystem services that they provide. These measures are vital for buying time for reefs while global action on climate change is implemented. Adaptive community-based strategies are critical to strengthen institutional management efforts. But government agencies need to transparently build local trust, empower local stakeholders, and foster co-management to be fully successful. Failing to achieve that could make community-based coral reef rehabilitation more challenging, and could potentially drive rapidly declining, transient coral reefs into the slippery slope to slime.

\section{Keywords}

Acropora cervicornis, Climate Change, Coral Farming, Extreme Weather Events

\section{Introduction}

\subsection{Unprecedented Coral Reef Decline}

Coral reefs have suffered a widespread decline through the Atlantic during the last three to four decades [1]-[3]. This has resulted in losing entire coral functional groups and in the net loss of coral reef ecosystem resilience, ecological functions, net services and benefits across multiple spatial scales. Staghorn coral populations, Acropora cervicornis (Lamarck, 1816), have collapsed across their geographic range in the western Atlantic over the last three to four decades [4]-[7]. Acroporid corals have also disappeared from many coral reefs in Puerto Rico where they are previously common [8] [9]. Staghorn coral used to dominate vast extensions of shallow to moderately deep (5 - $20 \mathrm{~m}$ ) fore-reef terraces across the Caribbean [10]-[12] for over the last 600,000 years through the Pleistocene [13]-[17]. It was also a dominant reef species even as far as the mid Miocene (3.5 M.A.) and Pliocene (15 M.A.) [18]. The long persistence of A. cervicornis across the geological record goes back to Neogene deposits (40 - 50 M.A.) across the northeastern Caribbean [19]. Nevertheless, current declining trends are unprecedented in the recent geological record [20] [21], suggesting non-natural causes for its rapid decline. This has prompted its listing as a critically endangered species on the International Union for the Conservation of Nature Red List, and its designation as a threatened species under the US Endangered Species Act across the US Caribbean since 2006.

Acroporid corals in general are highly vulnerable to impacts from different natural factors, such as disease epidemics [5] [22] [23], emergent microbial infections [24] [25], and hurricanes [26]-[29]. They are also susceptible to multiple human factors, including land-based source pollution (LBSP), mostly in the form of chronic sewage pollution, sedimentation and turbidity [1] [30]-[33], and climate change [34]. Acropora cervicornis can reproduce both sexually and asexually [35]-[38]. Nonetheless, natural recovery, with few exceptions, has been very limited and virtually inexistent in most localities across the region largely as a result of their extremely low densities, significant mean colony size reduction and geographical isolation of surviving colonies [39]. These factors can significantly reduce their reproductive potential, and impair successful sexual reproduction and larval recruitment. Sexual recruitment in A. cervicornis has been very limited or non-existent across the Caribbean Region [40]-[42], mostly as a result of recurrent climate-related disturbances such as increased sea surface tem- 
perature (SST) and massive coral bleaching [43]. Lack of recovery of A. cervicornis could result in a permanent decline in coral reef spatial heterogeneity and in losing a significant part of its essential fish habitat functions. Therefore, the use of low-tech coral farming and reef rehabilitation methods had become a paramount tool to enhance natural recovery ability of depleted reefs, foster the re-establishment of self-sustainable, sexually-reproducing populations on local reef scales, and contribute to sustainably maintaining and enhancing reef ecosystem functions and resilience.

\subsection{The Role of Coral Aquaculture and Coral Reef Restoration}

Coral aquaculture and coral reef restoration have become important tools to help replenish depleted coral reefs [44]-[52]. There has been a significant increase in coral farming activities at a global scale over the last decade [53], including the Wider Caribbean, which has involved a variety of low-tech approaches to propagate A. cervicornis, including the use of wire frames, wire coated frames, and a sort of horizontal line structures [54]. Early attempts to propagate A. cervicornis in Puerto Rico date back to 1980 [55]. There have been important recent efforts to replenish coral reefs in Puerto Rico impacted by significant vessel groundings through low-tech coral farming activities [56] [57]. Also, there have been successful participatory and collaborative efforts between the academia and community-based non-governmental organizations (NGOs) with an aim to mitigate or restore climate change-related impacts and depleted reefs historically impacted by military training activities [58] [59]. This effort has resulted in the successful implementation since 2003 of the Community-Based Coral Aquaculture and Reef Rehabilitation Program led by Sociedad Ambiente Marino (SAM) and the Coral Reef Research Group (CRRG) of the University of Puerto Rico’s Center for Applied Tropical Ecology and Conservation (CATEC), with the direct collaboration of NGO Coralations and the Culebra Island Fishers Association. The program has successfully propagated and reintroduced over 15,000 A. cervicornis colonies around Culebra since 2003. The general goals of the program include the aim to restore A. cervicornis depleted populations and to rehabilitate coral reef ecosystem functions by fostering increased fish and coral recruitment, and increased herbivory levels. These processes are critical for the sustainability of coral reef ecosystem functions and resilience under forecasted climate change scenarios [60].

\subsection{Climate Change and Extreme Weather Threats to Coral Reefs}

Climate change has become one of the most significant threats to coral reef ecosystems [61]. Forecasted trends of change based on climate modeling suggest major threats due to increasing SST and increased risk of massive coral bleaching events [62]. These could have potentially devastating consequences for selected reef-building species [63] [64] and for marine ecosystems [65]-[68]. Global-scale climate change impacts may also threaten the success of coral aquaculture and coral reef rehabilitation activities due to extreme weather events leaving base-communities nearly defenseless against factors such as declining reef accretion in face of increasing sea level rise (SLR), ocean acidification, net loss of ecosystem resilience and productivity, and declining socioeconomic value, services and benefits (i.e., losing fisheries sustainability potential, tourism revenues). Such impacts can be more critical for small island-nations with limited geographic, socio-economic, and human resources, particularly under non-sustainable economic models [69]. Nonetheless, studies addressing the impacts of climate-related factors such as increasing SST, increased tropical storm or hurricane frequency, or extreme rainfall events are missing. We postulate that a chronic increase in SST may increase the frequency and/or severity of extreme rainfall events and hurricanes. In turn, this should result in an increased frequency and/or severity of impacts from sediment-laden runoff pulses and LBSP to coral reefs and to community-based coral farming efforts. This suggests the need to test low-tech adaptive strategies to minimize such impacts and maximize coral growth and survival. Further, the role of no-take marine protected areas (MPAs) as potential buffers of multiple anthropogenic disturbance impacts to coral reefs, including climate change, still remains controversial [70] [71]. We suggest that even a no-take MPA designation is not enough to ameliorate impacts from climate change and extreme weather events. Their potential benefit could be further diminished by LBSP. There are still no published accounts comparing outputs of coral farming within and outside no-take MPAs.

This study was aimed at addressing the impacts of high SST, hurricanes, and extreme rainfall events on community-based low-tech A. cervicornis farming in Culebra Island, Puerto Rico. We tested two different methods to propagate corals as an adaptive strategy to mitigate impacts by hurricanes, extreme rainfall and sediment-laden runoff pulses (Figure 1). Finally, results were compared between coral farming sites located within a notake MPA and control sites outside open to fishing. 


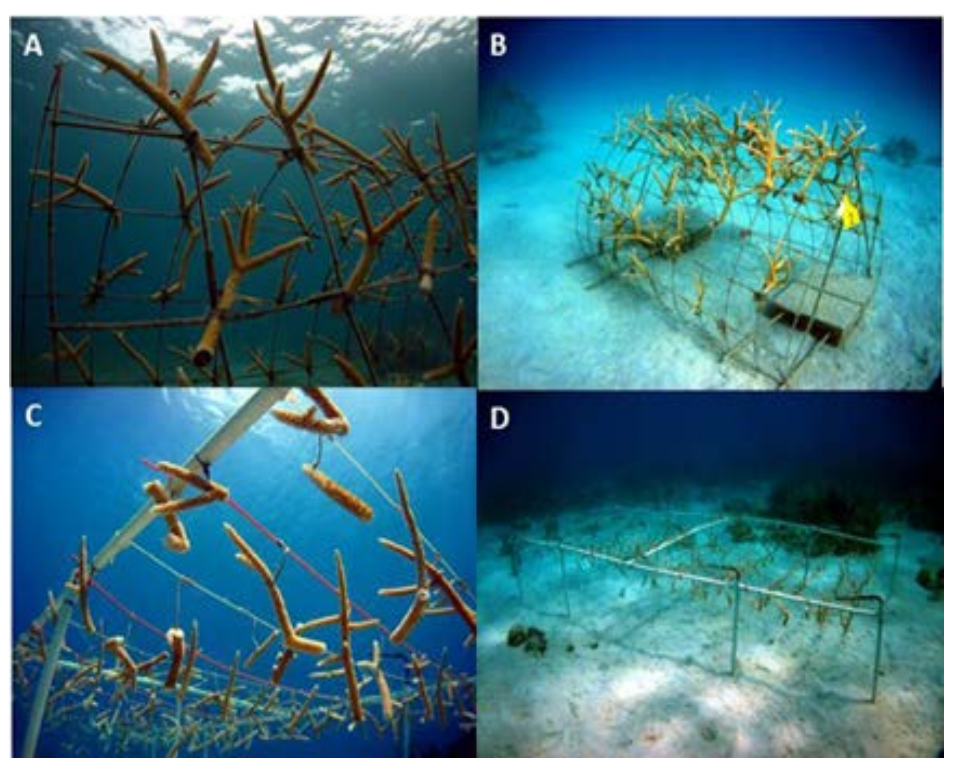

Figure 1. Example of community-based, low-tech Acropora cervicornis farming units. (A) and (B) Wire "A frames"; (B) and (C) Horizontal line nurseries (HLN) or "table” units.

\section{Methods}

\subsection{Study Sites}

Coral farming activities were carried out at three different sites in Culebra Island, a $72 \mathrm{~km}^{2}$ volcanic island, with 2000 residents, and located at $27 \mathrm{~km}$ off eastern Puerto Rico, in the Caribbean Sea (Figure 2). Bahía Tamarindo (BTA) and Punta Melones (PME) are located within the Canal Luis Peña no-take Natural Reserve (CLNR). Punta Soldado (PSO) is located at a control site open to fishing. Propagules from wild coral populations were obtained from Culebrita Island (CBT). All coral farming was conducted at depths ranging from 4 to $6 \mathrm{~m}$, over sandy and rubble bottoms adjacent to fringing reefs. Each "A frame" unit consisted of a $180 \times 150 \mathrm{~cm}$ wire panel $(15 \times 15 \mathrm{~cm}$ sq. holes) partially bent to form an "A" shape structure that was anchored to the bottom using two concrete blocks (50 kg each), and a combination of $2.1 \mathrm{~m}$ rebars driven to the bottom, sand screws, and polypropylene lines. "A frames" supported up to 80 colonies each attached using plastic ties. Each horizontal line nursery (HLN) unit consisted of a $3 \times 3$ m square-shaped "table" with six legs built using $1.88 \mathrm{~cm}$-wide PVC pipes. Corals were suspended at approximately $0.9 \mathrm{~m}$ off the bottom from fishing line or trimmer cable using plastic covered telephone copper wire. HLN units were anchored as above. Each unit also supported 80 colonies. Materials used in this study were commonly available in hardware stores, were not expensive and units were easy to construct and implement by local community-based volunteers. This project constituted part of the Community-Based Coral Aquaculture and Reef Rehabilitation Program which has been in operation since 2003.

\subsection{Sea Surface Temperature and Rainfall Patterns}

SST was permanently measured at each study site in Culebra Island using Hobo Temp V2 data loggers (Onset Computer Co.) placed a $5 \mathrm{~m}$ depth. Measurements were continuously obtained at 12 -min intervals during the entire two years of the project ( $\mathrm{N}=87,600 \mathrm{SST}$ lectures per site). Daily rainfall records were provided by William Kunke, resident of Culebra. The island has not had official rainfall records since 1975. Data on extreme rainfall events was also obtained from the Puerto Rico TJUA Doppler radar imagery using GRlevel 3 v.1.79 software (Gibson Ridge Software).

\subsection{Genetic Characterization of Acopora cervicornis Source Populations}

Samples from original A. cervicornis wild population sources selected for coral propagation were subjected to genetic analysis to determine their genetic identity. Genomic DNA was extracted from $\sim 5-7$ polyps with the 


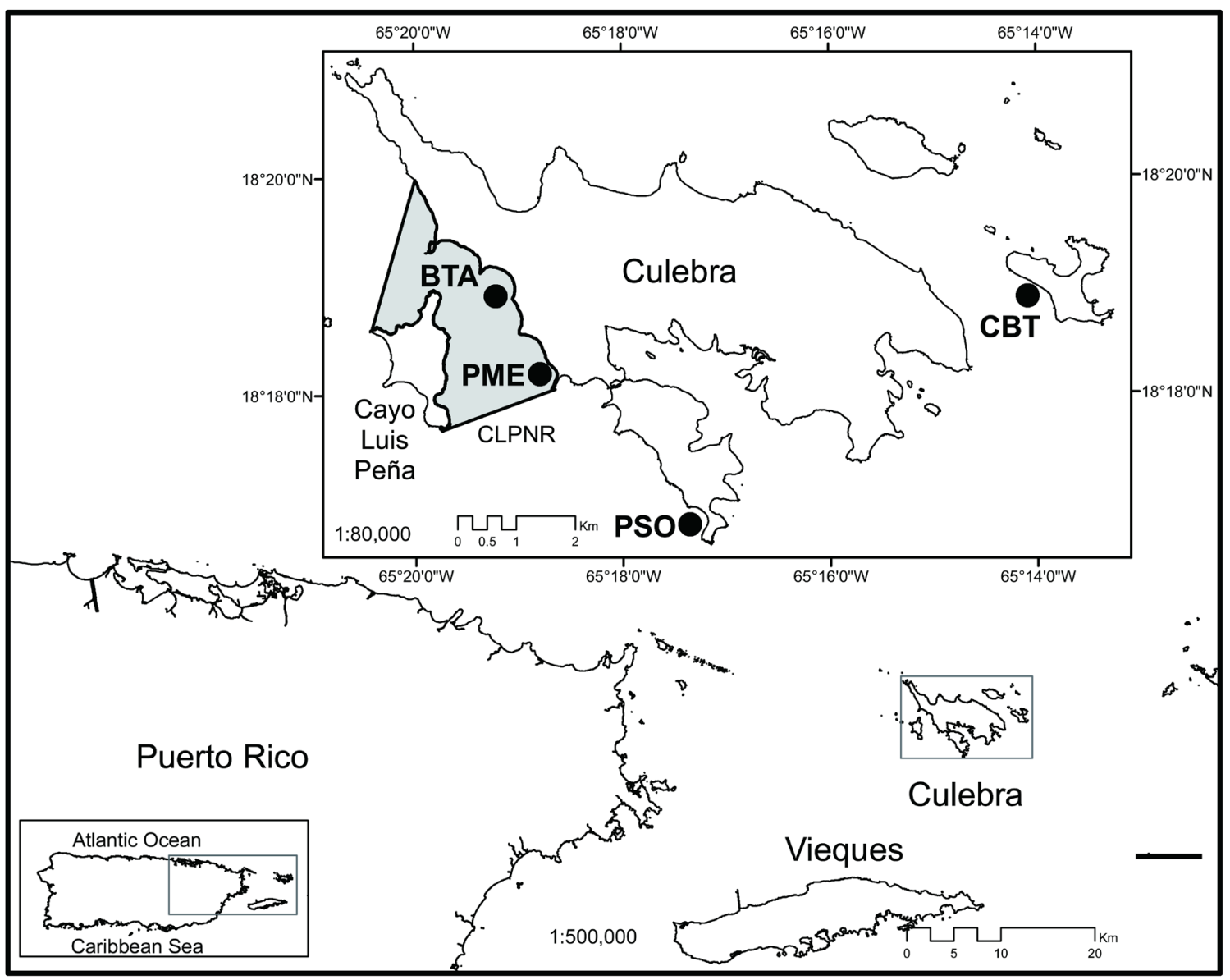

Figure 2. Study sites at Culebra Island, Puerto Rico. BTA = Bahía Tamarindo; PME = Punta Melones; PSO = Punta Soldado. CLPNR = Canal Luis Peña no-take Natural Reserve (gray shaded area). CBT = Culebrita Island (source of wild coral colonies).

DNeasy Blood \& Tissue Kit (Qiagen) following the manufacturer's animal tissue protocol from each sample. Samples were then screened for 4 polymorphic microsatellite markers [72], namely \#166, \#181, \#182 and \#207, following a modified protocol from [73]-[75]. PCR amplifications were performed in $10 \mu \mathrm{l}$ reactions, containing $1 \mu \mathrm{l}$ genomic DNA (5 - $15 \mathrm{ng} \cdot \mu^{-1}$ ), $0.8 \mathrm{mM}$ dNTPs, $0.1 \mu \mathrm{M}$ of forward primer with M13 tail, $0.1 \mu \mathrm{M}$ of fluorescently labeled M13, $0.2 \mu \mathrm{M}$ of reverse primer, $\mathrm{MgCl}_{2}(2 \mathrm{mM}), 0.3 \mu \mathrm{l}$ of $1 \mathrm{U} \cdot \mu \mathrm{l}^{-1}$ Taq DNA polymerase (Fermentas), and $1 \times$ of the PCR buffer. Temperature cycling was performed by denaturing $1 \mathrm{~min}$ at $94^{\circ} \mathrm{C}$, followed by 20 cycles of $20 \mathrm{~s}$ at $94^{\circ} \mathrm{C}, 35 \mathrm{~s}$ at $56^{\circ} \mathrm{C}$, and $30 \mathrm{~s}$ at $72^{\circ} \mathrm{C}$. Then, followed by 15 cycles of $20 \mathrm{~s}$ at $94^{\circ} \mathrm{C}, 35 \mathrm{~s}$ at $50^{\circ} \mathrm{C}$, and $30 \mathrm{~s}$ at $72^{\circ} \mathrm{C}$, and a $10 \mathrm{~min}$ extension step at $72^{\circ} \mathrm{C}$. Amplicons were diluted up to $50 \times$ to approach $10-$ $20 \mathrm{ng} \cdot \mathrm{\mu l}^{-1}$, and were run on an ABI3130xl Genetic Analyzer with ROX labeled size standards. Microsatellite alleles were scored using Gene Marker v2.2. The probability of identity (PI) is the probability of two samples with different genotypes to have identical haplotypes given a set of genetic markers. Identical haplotypes are then considered ramets of the same genet (clones of a same genotype) with a confidence probability PI. The Computation of PI was performed in Genalex v6.4 [76].

\subsection{Coral Farming Sampling Design}

Coral farming was conducted in 2011-2012 and in 2012-2013 using wire "A frames” (Figure 1(A), Figure 1(B)). HLN or "table" units were also used in 2012-2013 at BTA and PSO (Figure 1(C), Figure 1(D)). Each farm was subdivided in 6 replicate units per site, one per each genetic clone, at approximately $5 \mathrm{~m}$ depth. A total of 80 replicate 22 cm-long fragments per clone, per site, were grown during a year in 2011-2012 in "A frames", when fragments were harvested and used either for out planting or for coral farm expansion. Fragments ranging from 
32 to $37 \mathrm{~cm}$-long were used in “A frames” during 2012-2013, while $15 \mathrm{~cm}$ fragments were used for HLN units. Fragment survival, growth (total linear extension), total branch abundance ( $>0.5 \mathrm{~cm}$ length), branchiness index (BI) (\# harvestable branches $>6 \mathrm{~cm}$ ), percent live tissue cover, percent recent mortality, percent old mortality, causes of mortality (when possible to identify), disease prevalence, percent bleaching frequency, and bleaching severity index (BSI) were monitored in 20 permanently marked, haphazard replicate fragments per clone at each site, at fixed 0, 1, 3, 6, 9 and 12 month-intervals during each cycle. Data were also collected during month 5 (September 2011) of the first year to address impacts by Hurricane Irene, and tropical storms Emily and María. Colony growth measurements were performed using a cm-calibrated metric line at $0.2 \mathrm{~cm}$ resolution. BSI was visually determined on all monitored colonies using a semi-quantitative classification system using the following scoring points: 1) unbleached coral; 2) pale bleaching; 3) patchy bleaching; 4) mostly bleached; 5) fully bleached. Scores per clone were averaged for each 20 coral cohort. Predator density was also documented, including corallivore snails (Coralliophila caribaea, C. abbreviata), fireworm (Hermodice carunculata), territorial damelfishes (Pomacentridae), and butterflyfish (Chaetodontidae). Data during 2012-2013 were simultaneously collected from "A frame" and HLN units at similar fixed time intervals.

Selected coral farming data from the 2011-2012 and the 2012-2013 cycles were individually tested using multivariate approaches with PRIMER-E v6.1.16 \& PERMANOVA+ v1.0.6 statistical package [77] [78]. The 20112012 data were tested using a three-way permutational analysis of variance (PERMANOVA) for site (BTA, PME, PSO), time $(0,1,3,5,6,9,12$ months), clone ( $n=6$ clones), and management effects (no-take MPA, control site outside). PERMANOVA was used to test the null hypothesis of no significant difference in mean values of any of the coral parameters measured, as well as their interaction effects. Data from the 2012-2013 cycle were tested using a four-way PERMANOVA for site (BTA, PME, PSO), time (0, 1, 3, 6, 9, 12 months), clone ( $\mathrm{n}=6$ clones), method (A frames, HLN), and management effects (no-take MPA, control site outside). Data were square root-transformed prior to analysis. All tests were based in 10,000 permutations.

\section{Results}

\subsection{Sea Surface Temperature}

SST during the study period of time always exceeded every monthly historical mean value (Figure 3(A)). This resulted in positive SST anomalies during the entire 28-month long project extent. According to historical SST records across the northeastern Caribbean, the mean monthly maximum (MMM) SST $\left(28.5^{\circ} \mathrm{C}\right)$ is often typical of late-August to mid-October. However, the MMM was reached and exceeded as early as mid June during 2011 and 2012, extending down to November. Hot spot SST $\left(28.5^{\circ} \mathrm{C}+1^{\circ} \mathrm{C}\right)$ was reached or exceeded for about 5 continuous weeks (Degree Heating Weeks; DHW) during 2011, but only during two weeks in 2012 and 2013. The highest SST anomaly of 2011 was observed during late August $\left(+1.69^{\circ} \mathrm{C}\right)$, and the lowest at early March $\left(+0.16^{\circ} \mathrm{C}\right)$. The highest SST anomaly of 2012 was documented during early November $\left(+1.87^{\circ} \mathrm{C}\right)$, and the lowest during late April $\left(+0.23^{\circ} \mathrm{C}\right)$. The highest SST anomaly of 2013 occurred also during early November $\left(+1.65^{\circ} \mathrm{C}\right)$, and the lowest during late April $\left(+0.20^{\circ} \mathrm{C}\right)$. Winter SST anomalies were also a concern during this study with $+1.49^{\circ} \mathrm{C}$ during late January $2011,+1.78^{\circ} \mathrm{C}$ during early January 2012, and $+1.65^{\circ} \mathrm{C}$ during early January 2013 . Mean seasonal SST anomalies ranged during 2011 from $+0.50^{\circ} \mathrm{C}$ in Spring to +1.16 in the Summer, from $+0.65^{\circ} \mathrm{C}$ in the Spring to $+1.36^{\circ} \mathrm{C}$ in Fall during 2012, and from $+0.65^{\circ} \mathrm{C}$ in Spring to $+1.42^{\circ} \mathrm{C}$ in Fall (Figure $3(\mathrm{~B})$ ). The presence of year-round positive SST anomalies suggests continuing physiological stress for coral colonies and potentially increased vulnerability to other local sources of stress (i.e., extreme rainfall, sedimentladen runoff, LBSP).

\subsection{Extreme Rainfall Events: A Proxy for Recurrent Runoff and LBSP Pulse Impacts}

Culebra Island has a subtropical dry climate, with a historical annual rainfall mean of $(84.5 \mathrm{~cm})$ based on $1907-$ 1975 records (http://weather-warehouse.com). Annual rainfall total for the periods of 1907, 1909, 1919, and 1955-1972 averaged $85.6 \mathrm{~cm}$, and ranged from $36.2 \mathrm{~cm}$ in 1967 to $142.8 \mathrm{~cm}$ in 1970 [79]. But mean annual rainfall trends have increased to $114.4 \mathrm{~cm}$ during the period of $1987-2013$, or $34 \%$ above the historical mean (William Kunke, unpub. data). Mean rainfall in Culebra Island during 2010 reached a record $189.8 \mathrm{~cm}$. During 2011, rainfall reached $111 \mathrm{~cm}$, only $74.8 \mathrm{~cm}$ in 2012, and $107.3 \mathrm{~cm}$ in 2013. Recent rainfall trends between 2010 and 2013 have been $+125 \%,+31 \%,-11.8 \%$, and $+27 \%$ in relation to historical annual mean. There were also 

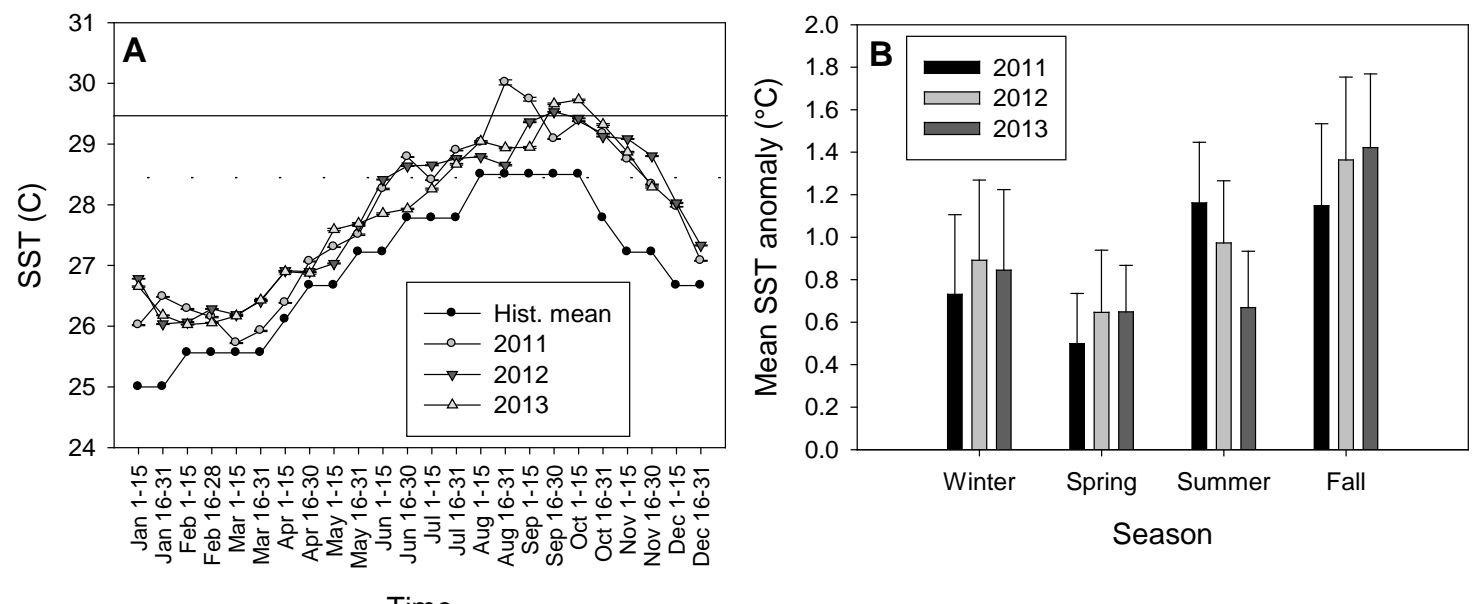

Figure 3. Sea surface temperature (SST) records at Culebra Island between January 2011 and November 2013: (A) Mean annual values. Dashed horizontal line $=$ mean monthly maximum $\left(\mathrm{MMM}=28.5^{\circ} \mathrm{C}\right)$. Continuous horizontal line $=$ hot spot $\left(28.5^{\circ} \mathrm{C}+1^{\circ} \mathrm{C}\right)$. (B) Mean seasonal SST anomaly ( $\pm 95 \%$ confidence intervals).

significant impacts by extreme rainfall events in Culebra during recent years that were documented from Puerto Rico TJUA Doppler radar imagery using GRlevel 3 software, which were not recorded from rain gauge data. There is record of at least 20 different extreme rainfall events in Culebra Island only for the period of May to September 2011, many of which had direct impacts on watersheds adjacent to coral farming sites and resulted in major runoff episodes that affected coral survival.

For our purpose, extreme rainfall was defined as heavy rainfall in a short period of time (i.e., $>2.5 \mathrm{~cm} / \mathrm{hr}$ ). There were six events recorded in a local rain gauge during May 2011 (4 - $15 \mathrm{~cm} /$ event), five during June ( 4 - $15 \mathrm{~cm} / \mathrm{event}$ ), four during July (5 - $13 \mathrm{~cm} /$ event), and two during August $(13 \mathrm{~cm}$ and $18 \mathrm{~cm} /$ event) associated to tropical storm Emily and Hurricane Irene (August, 2011). These also produced $2 \mathrm{~m}$, and 4 - 5 m swells, respectively.

Based on rain gauge data, summer extreme events in 2011 represented rainfall anomalies of $127 \%, 140 \%$, and $152 \%$ in relation to mean monthly values in May, June, and August, respectively (Figure 4). However, Doppler data suggested extreme rainfall events that resulted in rainfall records 319\% above mean May value, 521\% in June, $246 \%$ in July, $168 \%$ in August, and 165\% in September. All of these events resulted in coral mortality episodes in both wild and cultured A. cervicornis populations as a result of rapid shut-down reaction (SDR) and tissue loss following heavy rainfall and sediment-laden runoff.

The northeastern Caribbean Region was also impacted during 2012 and 2013 by several significant rainfall events, as well as by recurrent long-period bottom swells. These included important events such as tropical storm Isaac (August 2012), which also produced waves of approximately $4 \mathrm{~m}$ across coral farms. During late October 2012 long-period swells from Hurricane Sandy produced $5 \mathrm{~m}$ NW breaking waves, in combination with bottom swells across the region, and produced Doppler estimates of $13 \mathrm{~cm}$. Another important event in December 2012 was tropical storm Rafael, which produced not much rain, but generated 3 - 4 m swells. Bottom swells resulted in significant sediment resuspension. During the first 9 months of 2013 Culebra Island was initially impacted by three consecutive months of very dry conditions $(<2.5 \mathrm{~cm})$, followed by a few significant isolated strong rainfall episodes associated to the mid-Atlantic through positioning over Culebra. These included extreme events during late March (13 cm over a few hours) and a strong tropical wave during mid June (20 cm over a few hours). Then, tropical storm Chantal (July) produced some significant rain bands over eastern Puerto Rico and Culebra, with 2.5 m-high SW swells and a monthly rainfall anomaly of 215\%. Tropical storm Gabrielle (September) produced about $18 \mathrm{~cm}$ of rain over Culebra in about 48 hours. Runoff impacts by recurrent storm events, particularly those associated to passing tropical storms, were magnified by the recurrent practice of the Culebra Island municipal government of clearing all vegetation across several small creeks and natural drainage channels adjacent to urban areas as a preventive measure to manage potential flooding. The end product of such practices is extreme runoff pulse events and major erosion of ephemeral stream banks with significant concomitant turbidity impacts on costal ecosystems. 


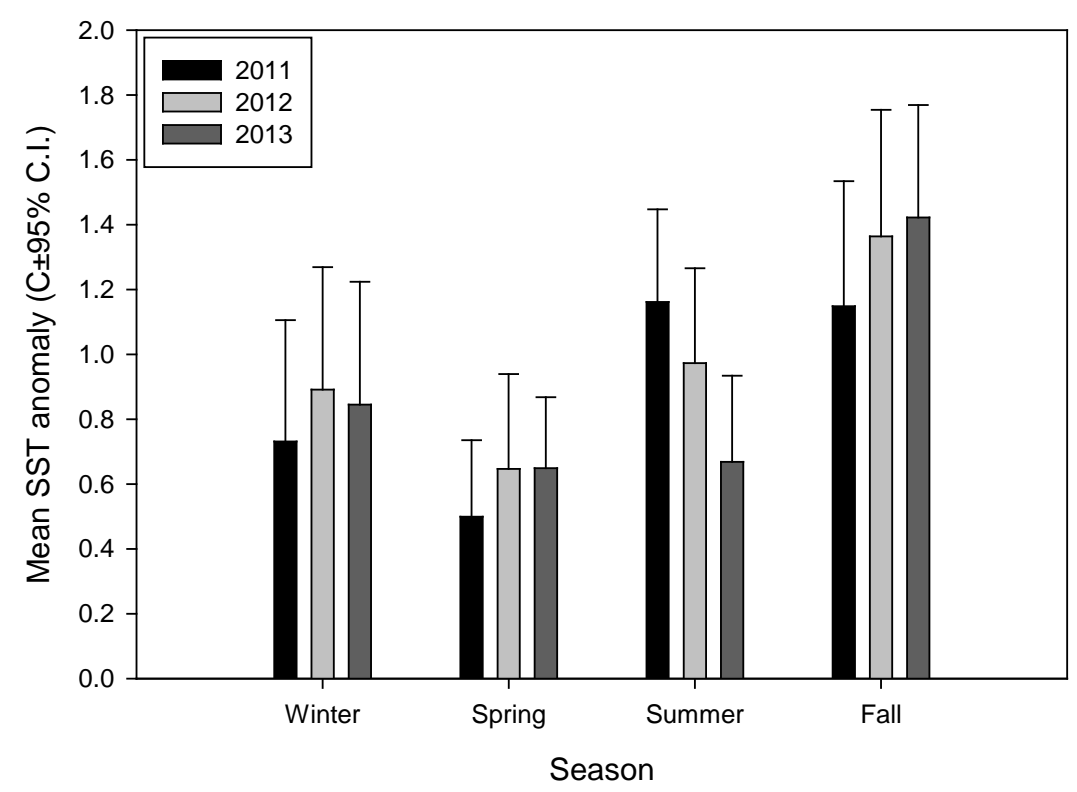

Figure 4. Mean monthly rainfall anomaly from Culebra Island during the project (2011-2013) in comparison to 1907-1975 mean (http://weather-warehouse.com). Data source: William Kunke (unpub. data).

\subsection{Genetic Characterization of Acropora cervicornis Source Populations}

At least six different haplotypes within the eight samples from A. cervicornis wild source populations were found in this study. One of the haplotypes (H6) included several ramets (clones, PI $=1.3 \times 10^{-3}$ ), represented by samples \#09 and \#10. Missing values for alleles for 3 out of 4 markers in sample \#7 prevented ruling out clonality for this sample, as its profile for marker \#207 made it a possible clone of haplotypes H1, H2, H3 or H6. Based on our eight samples, the probability for two different genotypes to have identical haplotypes by chance (PI) using these four microsatellite markers was $\sim 1.3 \times 10^{-3}$. But it is likely to be well underestimated due to the low number of samples at our disposition. By comparison, the PI calculated on the combination of the same four markers based on A. palmata 306 haplotypes [80] was estimated to be $\sim 7.9 \times 10^{-6}$. Therefore, it was a reasonable assumption that identical haplotypes represented different biological clones.

\subsection{Coral Farming (2011-2012)}

In spite of hurricane and extreme rainfall impacts during 2011, A. cervicornis farming during the first year was highly successful. Corals in "A frame" units showed $84 \%$ and $78 \%$ survival rate at BTA and PSO, respectively, after the first year (Figure 5(A)). Survival rate at PME reached only 57\% due to significant mechanical impacts by Hurricane Irene during August 2011, which caused localized destruction of some of the farming units and significant immediate and delayed coral mortality due to SDR and a White Band Disease-like (WBDL) condition. Also, frequent extreme rainfall events caused recurrent sediment-laden, nutrient-loaded turbid runoff impacts. PME, as well as BTA, received substantial recurrent runoff impacts. PME farms were eventually relocated after September 2011 to an alternative site adjacent to BTA, where surviving fragments showed an outstanding recovery. Coral fragment survival rates were also highly site-specific (Table 1). Temporal and management effects significantly influenced coral colony survival rates in "A frame" units, but clone variation did not, which means that extreme rainfall events had widespread adverse impacts among all clones in the population. Most interaction effects were also highly significant. Mean percent live tissue cover on coral farms after one year was 89\% at BTA, 93\% at PME (based on data from colonies that survived physical destruction by Hurricane Irene), and $91 \%$ at PSO (Figure 5(B)). Coral colonies showed rapid and remarkable tissue regeneration after hurricane sand blasting impacts. Temporal patterns, site effects and management effects were highly significant, producing a clear spatio-temporal gradient. Site $\times$ time, time $\times$ clone, management $\times$ site, management $\times$ time, and management $\times$ site $\times$ time interactions were also significant. 
Table 1. Three-way PERMANOVA of coral fragments from “A frame” units (2011-2012).

\begin{tabular}{ccccccc}
\hline Variable & d.f.* & $\begin{array}{c}\text { Survival rate } \\
\text { pseudo-F }(p)\end{array}$ & $\begin{array}{c}\text { \% live tissue } \\
\text { pseudo-F }(p)\end{array}$ & $\begin{array}{c}\text { Fragment size } \\
\text { pseudo-F }(p)\end{array}$ & $\begin{array}{c}\text { Branch abundance } \\
\text { pseudo-F }(p)\end{array}$ & $\begin{array}{c}\text { Branchiness } \\
\text { index pseudo-F }(p)\end{array}$ \\
Time & 6,119 & $12.59(<0.0001)$ & $8.88(<0.0001)$ & $11.81(<0.0001)$ & $7.63(<0.0001)$ & $10.32(<0.0001)$ \\
Site & 2,123 & $10.57(<0.0001)$ & $4.21(0.0120)$ & $4.98(0.0096)$ & $6.11(0.0019)$ & $4.45(0.0094)$ \\
Clone & 5,120 & $1.33(\mathrm{NS})^{* *}$ & $0.60(\mathrm{NS})$ & $2.14(\mathrm{NS})$ & $5.03(0.0003)$ & $2.04(0.0094)$ \\
Management & 1,124 & $4.84(0.0311)$ & $3.99(0.0429$ & $8.90(0.0029)$ & $11.80(0.0008)$ & $8.67(0.0017)$ \\
Site $\times$ time & 20,105 & $10.92(<0.0001)$ & $6.70(<0.0001)$ & $5.51(<0.0001)$ & $3.79(<0.0001)$ & $4.33(<0.0001)$ \\
Site $\times$ clone & 17,108 & $3.40(0.0002)$ & $1.21(\mathrm{NS})$ & $2.48(0.0020)$ & $2.91(<0.0001)$ & $2.90(0.0005)$ \\
Time $\times$ clone & 41,84 & $1.72(0.0231)$ & $1.56(0.0467)$ & $2.60(<0.0001)$ & $2.43(0.0004)$ & $2.10(0.0015)$ \\
Mgmt. $\times$ site & 2,123 & $12.59(<0.0001)$ & $4.21(0.0126)$ & $4.98(0.0082)$ & $6.11(0.0029)$ & $4.45(0.0114)$ \\
Mgmt. $\times$ time & 13,112 & $6.47(<0.0001)$ & $5.78(0.0002)$ & $8.11(<0.0001)$ & $5.68(<0.0001)$ & $6.46(<0.0001)$ \\
Mgmt. $\times$ clone & 11,114 & $2.16(0.0237)$ & $1.11(\mathrm{NS})$ & $2.60(0.0051)$ & $5.13(<0.0001)$ & $2.31(0.0096)$ \\
Mgmt. $\times$ site $\times$ time & 20,105 & $10.92(<0.0001)$ & $6.70(<0.0001)$ & $5.51(0.0051)$ & $3.79(<0.0001)$ & $4.33(<0.0001)$ \\
Mgmt. $\times$ time $\times$ clone & 83,42 & $0.98(\mathrm{NS})$ & $0.89(\mathrm{NS})$ & $2.17(0.0047)$ & $2.15(0.0036)$ & $1.26(\mathrm{NS})$ \\
Mgmt. $\times$ site $\times$ clone & 17,108 & $3.40(0.0002)$ & $1.21(\mathrm{NS})$ & $2.48(0.0019)$ & $3.91(<0.0001)$ & $2.90(<0.0001)$ \\
\hline
\end{tabular}

${ }^{*}$ Degrees of freedom (within, between); ${ }^{* *} \mathrm{NS}=$ not significant $(p>0.05)$.
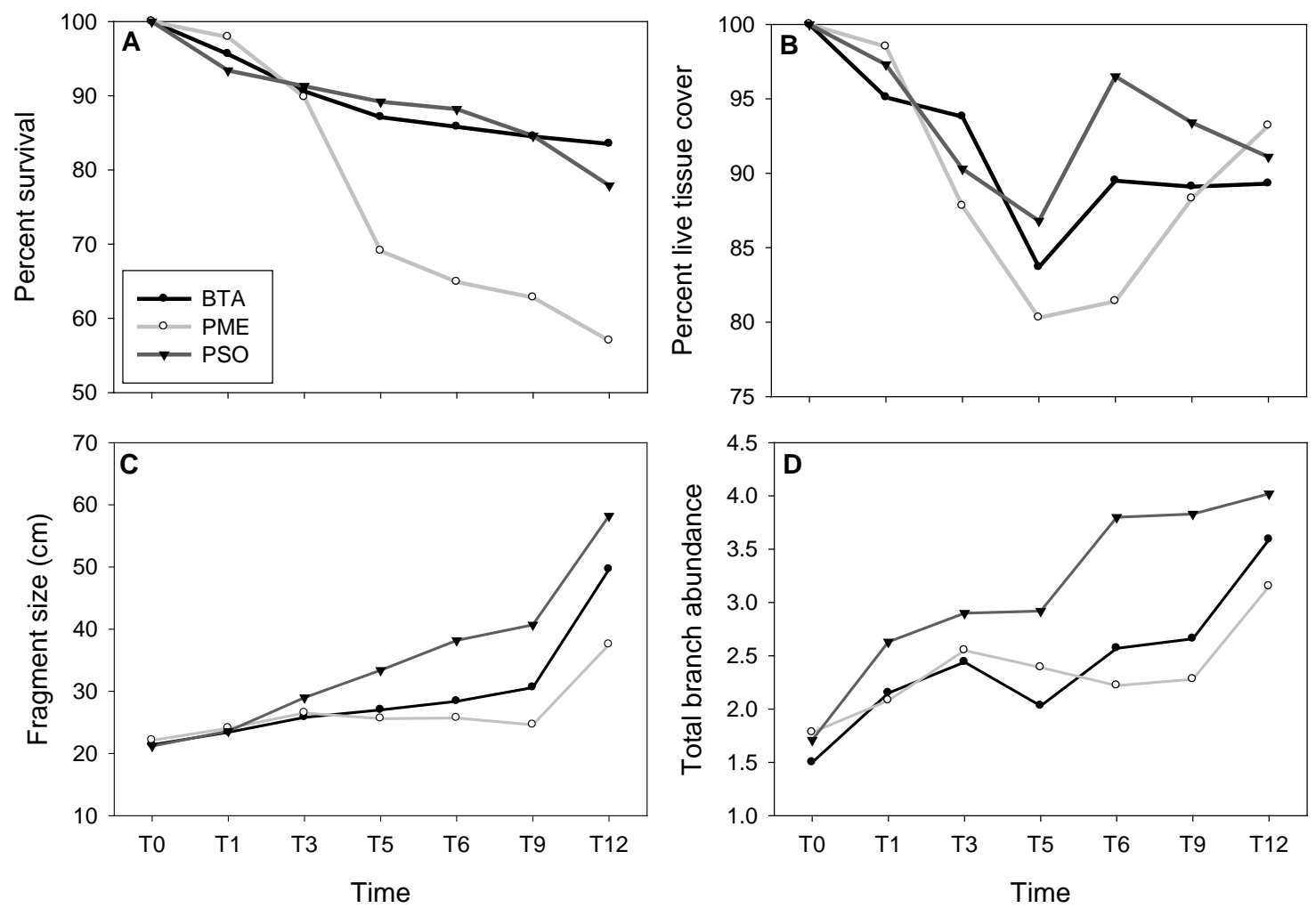

Figure 5. Coral fragment parameters mean values in "A frames" during 2011-2012: (A) Percent survival rates; (B) Percent live tissue cover; (C) Fragment size (cm); and (D) Total branch abundance. 
Mean total coral colony length after one year at BTA increased from 21.4 to $49.6 \mathrm{~cm}(28.2 \mathrm{~cm} / \mathrm{y})$, from 22.1 to $37.5 \mathrm{~cm}(15.4 \mathrm{~cm} / \mathrm{y})$ at PME (based on data from colonies that survived physical destruction by Hurricane Irene), and from 21.2 to $58.2 \mathrm{~cm}(37 \mathrm{~cm} / \mathrm{y})$ at PSO (Figure 5(C)). The magnitude of coral colony growth was $132 \%$ at BTA, $70 \%$ at PME, and $175 \%$ at PSO. Overall mean monthly skeletal extension at BTA was $2.35 \mathrm{~cm}$, $1.28 \mathrm{~cm}$ at PME, and $3.08 \mathrm{~cm}$ at PSO. PSO was the location with the lowest runoff impacts. Temporal patterns, site effects and management effects were highly significant (Table 1). Interaction effects were also significant.

Mean coral branch abundance after one year at BTA increased from 1.50 to 3.59 branches/colony, from 1.78 to 3.15 branches/colony at PME (based on data from colonies that survived physical destruction by Hurricane Irene), and from 1.71 to 4.02 branches/colony at PSO (Figure 5(D)). The magnitude of increase in coral colony branch abundance was $139 \%$ at BTA, $77 \%$ at PME, and $135 \%$ at PSO, which also reflects the limitation imposed by hurricane impacts. Temporal patterns, site effects, clone and management effects were highly significant (Table 1). Interaction effects were also significant. Mean coral branchiness index at BTA increased from 0.26 to 1.84 branches/colony, from 0.17 to 1.19 branches/colony at PME (based on data from colonies that survived physical destruction by Hurricane Irene), and from 0.24 to 2.34 branches/colony at PSO. This index represents the number of harvestable branches $>6 \mathrm{~cm}$ long. The magnitude of coral branchiness index increase was $608 \%$ at BTA, $600 \%$ at PME, and $875 \%$ at PSO (Figure 6), which represents a 6 to nearly 9-fold increase in the abundance of harvestable branches per colony, in spite of hurricane and extreme rainfall effects. Temporal patterns, site effects, clone and management effects were highly significant (Table 1). Almost all interaction effects were also significant.

Variability in coral colony conditions, including SDR and WBDL showed no significant spatio-temporal difference, or differences among clones (data not shown). But incidence of both conditions was always associated to major runoff episodes. Bleaching incidence was also highly variable in space and time, with no significant difference. Nonetheless, minor bleaching sporadically occurred in some colonies, with no mortality, just after initial transplanting as an acclimation response to altered irradiation at the outplanting site. Minor bleaching also occurred in some colonies during the late summer when SST was highest. Mean BSI reached 1.24 at BTA, 2.80 at PME, and 1.06 at PSO (out of a maximum scale value of 5.0 during full bleaching) after Hurricane Irene impact, suggesting only minor colony paling. BSI never exceeded 1.31 during the rest of the study. Bleaching was never a critical factor affecting project outcome. Corallivore gastropod (Coralliophila abbreviata, C. caribaea) recruitment pulses appear to be more active during Fall and late Spring, but no significant differences among sites were observed. Fireworm (Hermodice carunculata) predation was not a factor on coral farms, although predation damage was largely common on colonies outplanted to natural reef bottom at PSO, outside the no-take reserve.

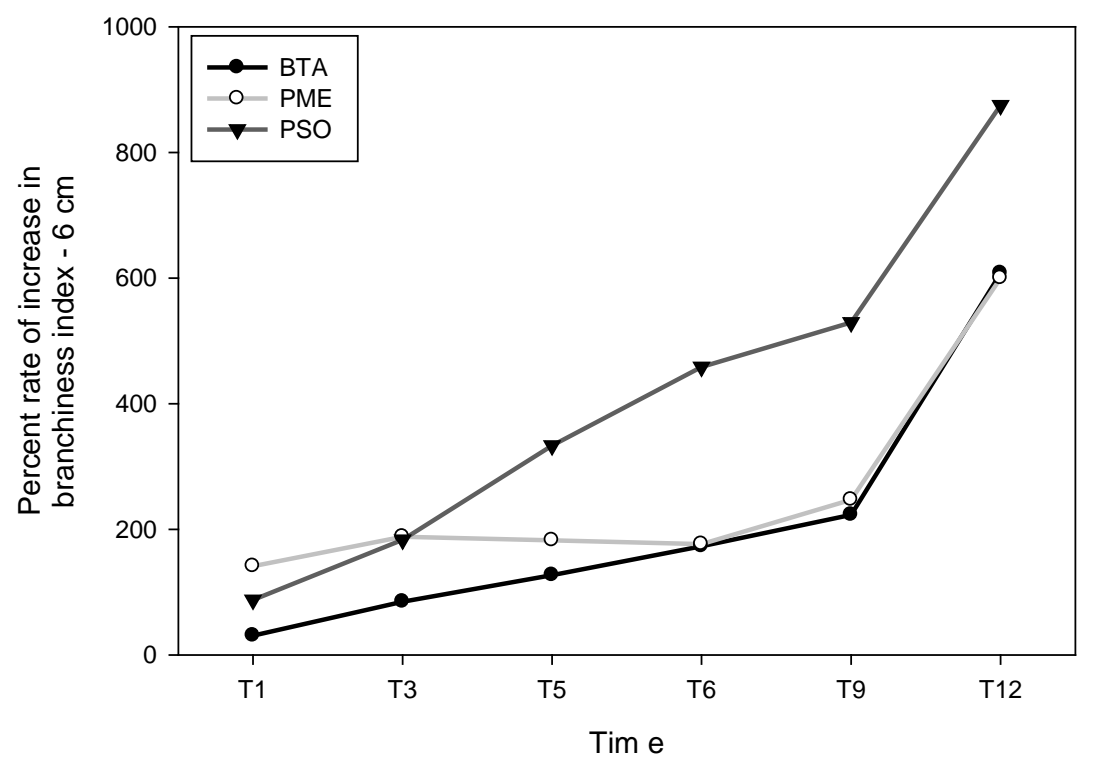

Figure 6. Percent rate of increase in branchiness index. 


\subsection{Coral Farming (2012-2013)}

During the period of 2012-2013 coral farming was expanded to simultaneously include “A frame” and HLN units. HLN or "table" units were designed and implemented to minimize sand blasting impacts and predation from corallivore gastropods and fireworms. Farms were impacted by tropical storms Ernesto (August), Isaac (August), and Rafael (December). Also, 3 - 5 m-high long-period swells generated from Hurricane Sandy across the northwestern Atlantic (October 2012) also swept coral farms causing localized breakage of large-sized colonies from older coral farms. However, a quick response from the community-based volunteers prevented any direct mortality. In spite of such impacts, A. cervicornis gowth during this cycle was highly successful, particularly for HLN units. Fragments in HLN units showed a significantly higher mean percent survival rate at PSO-T (99.6\%) and BTA-T (93.3\%), when compared to “A frame” units at PSO-A (83.7\%), PME-A (80.1\%), and at BTA-A (79.1\%) (Figure 7(A)). There were highly significant temporal, site, methods and management effects (Table 2). Survival rates were overall higher at PSO, and higher on HLN units. All interaction effects were also significant. Coral survival rates were significantly enhanced when colonies remained suspended in the water column in HLN units, in comparison to those that grew attached to the wire mesh structure of "A frames" under recurrent runoff pulse impacts and LBSP. Competing taxa, such as macroalgae, cyanobacteria, sponges, tunicates, bryozoans, fire coral (Millepora alcicornis, $M$. complanata), hydroids and reef oysters, can rapidly outcompete and overgrow A. cervicornis. Also, proliferating algal mats on the wire mesh structure after runoff impacts

Table 2. Four-way PERMANOVA of coral fragments from “A frame” and HLN units (2012-2013).

\begin{tabular}{|c|c|c|c|c|c|c|}
\hline Variable & d.f. ${ }^{*}$ & $\begin{array}{l}\text { Survival rate } \\
\text { pseudo-F }(p)\end{array}$ & $\begin{array}{l}\% \text { live tissue } \\
\text { pseudo-F }(p)\end{array}$ & $\begin{array}{l}\text { Fragment size } \\
\text { pseudo-F }(p)\end{array}$ & $\begin{array}{c}\text { Branch abundance } \\
\text { pseudo-F }(p)\end{array}$ & $\begin{array}{l}\text { Branchiness } \\
\text { index pseudo- } F(p)\end{array}$ \\
\hline Time & 5,180 & $16.04(<0.0001)$ & $6.96(<0.0001)$ & $18.68(<0.0001)$ & $17.11(<0.0001)$ & $11.50(<0.0001)$ \\
\hline Site & 4,181 & $11.55(<0.0001)$ & $34.01(<0.0001)$ & $15.35(<0.0001)$ & $14.68(<0.0001)$ & $22.23(<0.0001)$ \\
\hline Clone & 6,179 & $1.74(\mathrm{NS})^{* *}$ & 1.45 (NS) & $3.74(0.0015)$ & $2.17(0.0435)$ & $2.27(0.0242)$ \\
\hline Method & 1,184 & $42.12(<0.0001)$ & $132.31(<0.0001)$ & $53.63(<0.0001)$ & $47.76(<0.0001)$ & $87.99(<0.0001)$ \\
\hline Management & 1,184 & $8.63(0.0044)$ & $9.27(0.0030)$ & 0.45 (NS) & 1.23 (NS) & 1.71 (NS) \\
\hline Time $\times$ site & 29, 156 & $10.64(<0.0001)$ & $13.77(<0.0001)$ & $12.07(<0.0001)$ & $11.12(<0.0001)$ & $11.02(<0.0001)$ \\
\hline Time $\times$ clone & 41,144 & $2.43(0.0003)$ & 1.18 (NS) & $3.26(<0.0001)$ & $3.22(<0.0001)$ & $1.94(0.0009)$ \\
\hline Time $\times$ method & 11,174 & $26.83(<0.0001)$ & $32.76(<0.0001)$ & $28.95(<0.0001)$ & $24.93(<0.0001)$ & $29.62(<0.0001)$ \\
\hline Time $\times$ mgmt. & 11,174 & $9.79(<0.0001)$ & $4.53(<0.0001)$ & $9.08(<0.0001)$ & $8.79(<0.0001)$ & $5.94(<0.0001)$ \\
\hline Site $\times$ clone & 30,155 & $2.85(<0.0001)$ & $6.71(<0.0001)$ & $5.18(<0.0001)$ & $3.43(<0.0001)$ & $5.71(<0.0001)$ \\
\hline Site $\times$ method & 4,181 & $58.31(<0.0001)$ & $34.01(<0.0001)$ & $15.35(<0.0001)$ & $14.68(<0.0001)$ & $22.23(<0.0001)$ \\
\hline Site $\times$ mgmt . & 4,181 & $11.55(<0.0001)$ & $34.01(<0.0001)$ & $15.35(<0.0001)$ & $14.68(<0.0001)$ & $22.23(<0.0001)$ \\
\hline Clone $\times$ method & 12,173 & $4.81(<0.0001)$ & $12.94(<0.0001)$ & $9.18(<0.0001)$ & $6.92(<0.0001)$ & $11.94(<0.0001)$ \\
\hline Clone $\times$ mgmt. & 12,173 & $2.18(0.0146)$ & $1.80(0.0486)$ & $2.72(0.0009)$ & $1.41(0.0009)$ & 1.60 (NS) \\
\hline Method × mgmt. & 3,182 & $15.47(<0.0001)$ & $45.41(<0.0001)$ & $20.46(<0.0001)$ & $19.24(<0.0001)$ & $29.63(<0.0001)$ \\
\hline Time $\times$ site $\times$ method & 29,156 & $10.64(<0.0001)$ & $13.77(<0.0001)$ & $12.07(<0.0001)$ & $11.12(<0.0001)$ & $11.02(<0.0001)$ \\
\hline Time $\times$ site $\times$ mgmt & 29, 156 & $10.64(<0.0001)$ & $13.77(<0.0001)$ & $12.07(<0.0001)$ & $11.12(<0.0001)$ & $11.02(<0.0001)$ \\
\hline Site $\times$ clone $\times$ method & 30,155 & $2.85(0.0002)$ & $6.71(<0.0001)$ & $5.18(<0.0001)$ & $3.43(<0.0001)$ & $5.71(<0.0001)$ \\
\hline Site $\times$ clone $\times$ mgmt & 30,155 & $2.85(0.0002)$ & $6.71(<0.0001)$ & $5.18(<0.0001)$ & $3.43(<0.0001)$ & $5.71(<0.0001)$ \\
\hline Clone $\times$ method $\times$ mgmt. & 24,161 & $16.04(<0.0001)$ & $7.55(<0.0001)$ & $5.91(<0.0001)$ & $4.04(<0.0001)$ & $6.80(<0.0001)$ \\
\hline Site $\times$ clone $\times$ method $\times$ mgmt . & 30,155 & $11.55(<0.0001)$ & $6.71(<0.0001)$ & $5.18(<0.0001)$ & $3.43(<0.0001)$ & $5.71(<0.0001)$ \\
\hline
\end{tabular}

*Degrees of freedom (within, between); ${ }^{* *} \mathrm{NS}=$ not significant $(p>0.05)$. 
partially smothered coral tissue and functioned as a sporadic refuge for potential coral predator invertebrates, such as fireworms and corallivore gastropods. HLN units resulted in higher coral colony survival rates, better overall coral colony health condition, and never showed problems of predation by corallivore invertebrates.

Mean percent live tissue cover remained outstandingly high on HLN units, with mean values of $99.1 \%$ at PSO-T and of 96.5\% in BTA-T, in comparison to BTA-A (84.8\%), PME-A (86.6\%), and PSO-A (86.5\%) (Figure 7(B)). There were highly significant temporal, site, methods and management effects (Table 2). Percent live tissue cover was overall higher at non-reserve PSO and on HLN units. All interaction effects were significant, with the exception of time $\times$ clone interaction. Mean total colony length at the end of the second year was significantly higher at HLN units than at "A frames". Mean colony size at BTA-A increased from 30.6 to $63.8 \mathrm{~cm}(33.2 \mathrm{~cm})$, from 36.0 to $57.3 \mathrm{~cm}(21.3 \mathrm{~cm})$ at at PME-A, and from $36.0 \mathrm{~cm}$ to $62.4 \mathrm{~cm}(26.4 \mathrm{~cm})$ at PSO-A (Figure 7(C)). But the range of colony growth on HLN units had no precedent in comparison to a decade of coral farming data in Culebra, with a range from 13.8 to $43.1 \mathrm{~cm}(29.3 \mathrm{~cm})$ at BTA-T, and from 15.7 to $65.4 \mathrm{~cm}(49.7 \mathrm{~cm})$ at PSO-T. Mean percent increase in total colony length was $58.1 \%$ at PME-A, 92.7\% at PSO-A, and $107.3 \%$ at BTA-A. But mean percent increase in total colony length was $215 \%$ at BTA-T and $314 \%$ at PSO-T. The magnitude of skeletal extension of cultured corals on HLN units was significantly higher than those grown at "A frames". Monthly coral colony skeletal extension through the second year averaged $1.8 \mathrm{~cm}$ at PME-A, $2.2 \mathrm{~cm}$ at PSO-A, $2.8 \mathrm{~cm}$ at BTA-A, and $2.4 \mathrm{~cm}$ at BTA-T, and $4.1 \mathrm{~cm}$ at PSO-T. There were highly significant temporal, site, clone, and method effects (Table 2). Mean total colony length was overall higher at PSO, and on HLN units. All interaction effects were also significant. These results reflect the negative impacts produced by recurrent runoff pulses at BTA due to increased deforestation along the existing road to BTA.

Total branch abundance per colony during 2012-2013 shifted from 2.1 to 4.6 per colony at BTA-A, from 2.9 to 4.3 per colony at PME-A, and from 2.6 to 6.6 per colony at PSO-A, with a shift from 0.9 to 3.4 per colony at BTA-T, and from 1.1 to 5.4 at PSO-T (Figure 7(D)). The ratio of increase in total number of branches per colony was $149 \%$ at BTA-A, $59 \%$ at PME-A, $218 \%$ at PSO-A, $324 \%$ at BTA-T, and $438 \%$ at PSO-T. There were also highly significant temporal, site, clone, and method effects (Table 2). All interaction effects were significant, with the exception of methods $\times$ management interaction. Branchiness index $(>6 \mathrm{~cm})$ increased from
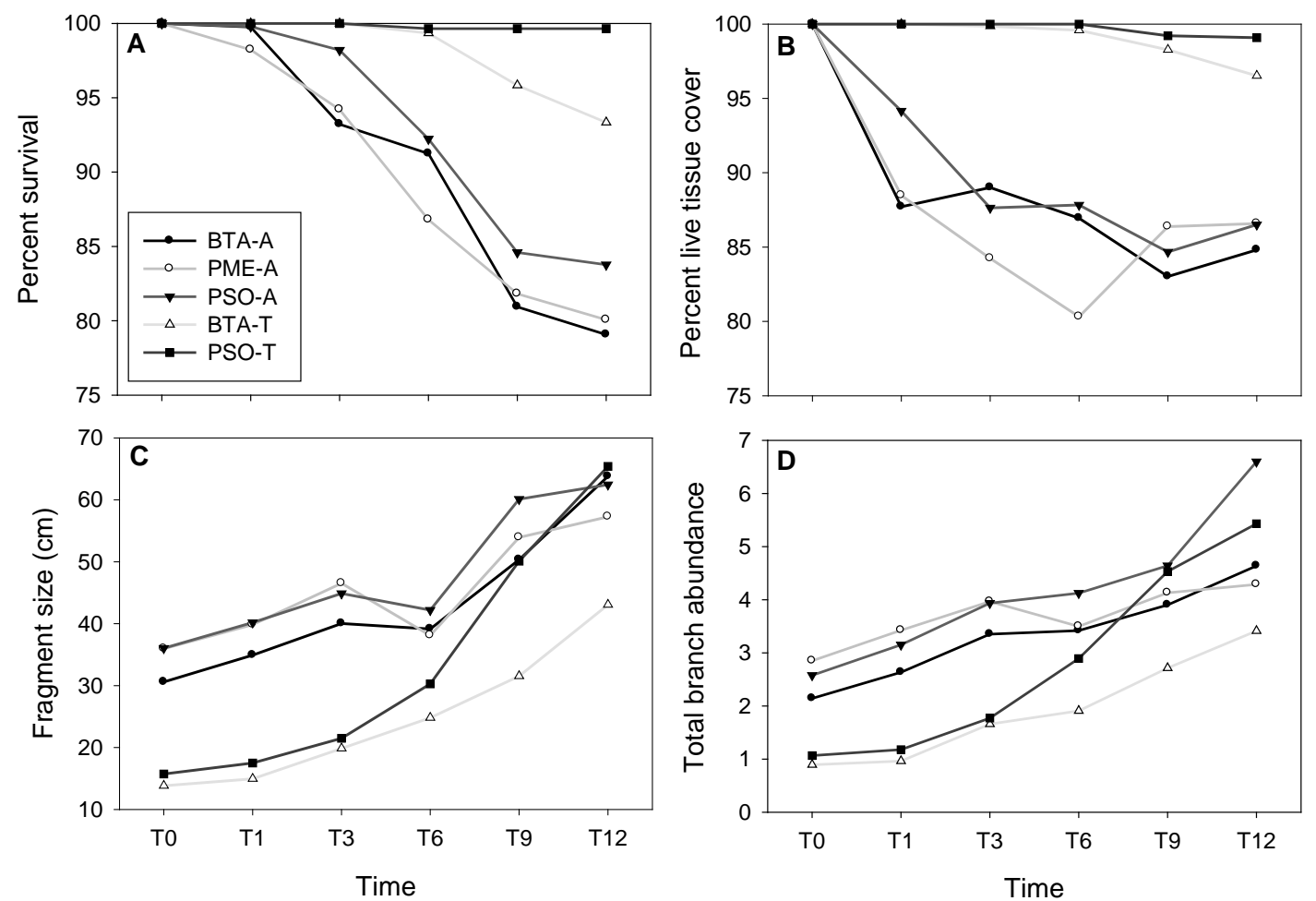

Figure 7. Coral fragment parameters mean values in “A frames” during 2012-2013: (A) Percent survival rates; (B) Percent live tissue cover; (C) Fragment size (cm); and (D) Total branch abundance. 
0.73 to 2.31 branches per colony at BTA-A, from 1.03 to 2.00 branches per colony at PME-A, and from 0.92 to 2.40 branches per colony at PSO-A. There was also an increase from 0.13 to 1.14 branches per colony at BTA-T, and from 0.10 to 1.60 branches per colony at PSO-T. Ratios of branchiness index reached by the end of the second year were $129 \%$ at PME-A, $237 \%$ at BTA-A, and $854 \%$ at PSO-A, or a 1.3 to 8.5 -fold increase (Figure 8). There was a $1875 \%$ increase at BTA-T and a $1925 \%$ increase at PSO-T, or a 19 -fold increase in branchiness index at each site. There were highly significant temporal, site, clone, and method effects (Table 2). All interaction effects were also significant. Coral skeletal extension and proportional colony growth and branch production were also significantly higher at PSO and at HLN units.

Coral bleaching was not a critical factor either through 2012-2013. Mean bleaching index values rarely exceeded 1.0 to 1.2, which meant that only sporadic fragments showed minor paling either rapidly after transplanting or during the late Summer. Spatio-temporal patterns were not significant. Similarly, bleaching frequency remained fairly low at the end of the second year, and with very limited impacts that were largely clone-specific and limited to the warmest period of late Summer-Fall of 2012. Bleaching was not considered a cause of coral mortality through the entire project.

\section{Discussion}

This project produced important lessons for adapting future community-based coral farming and coral reef rehabilitation efforts to forecasted climate changing conditions. Lessons include aspects regarding wild population source propagule selection to maintain high genetic diversity, coral farming site selection, impacts from LBSP and the crititical significance of managing adjacent land uses, and adaptive modifications to coral farming methods to improve success under changing environmental conditions. There were also important lessons learned regarding community-based participation in coral reef management activities.

\subsection{State-of-the-Art Genetic Tools vs. Low-Tech Traditional Field Identification of Clones}

Maintaining high genetic clone diversity should be a critical component of every coral aquaculture and coral reef rehabilitation project to buffer against any future impacts by disease outbreaks, other epizootics, massive bleaching or environmental variability associated to local human factors or climate change. State-of-the-art genetic characterization confirmed that the six coral clones of A. cervicornis used in coral farms in this study were different genetic individuals. Genetic diversity and structure in scleractinian corals vary significantly, reflecting the evolutionary differences between species, but also the type of genetic markers employed. Microsatellite markers were more successful at detecting weak genetic structure than mitochondrial markers, ITS or allozymes

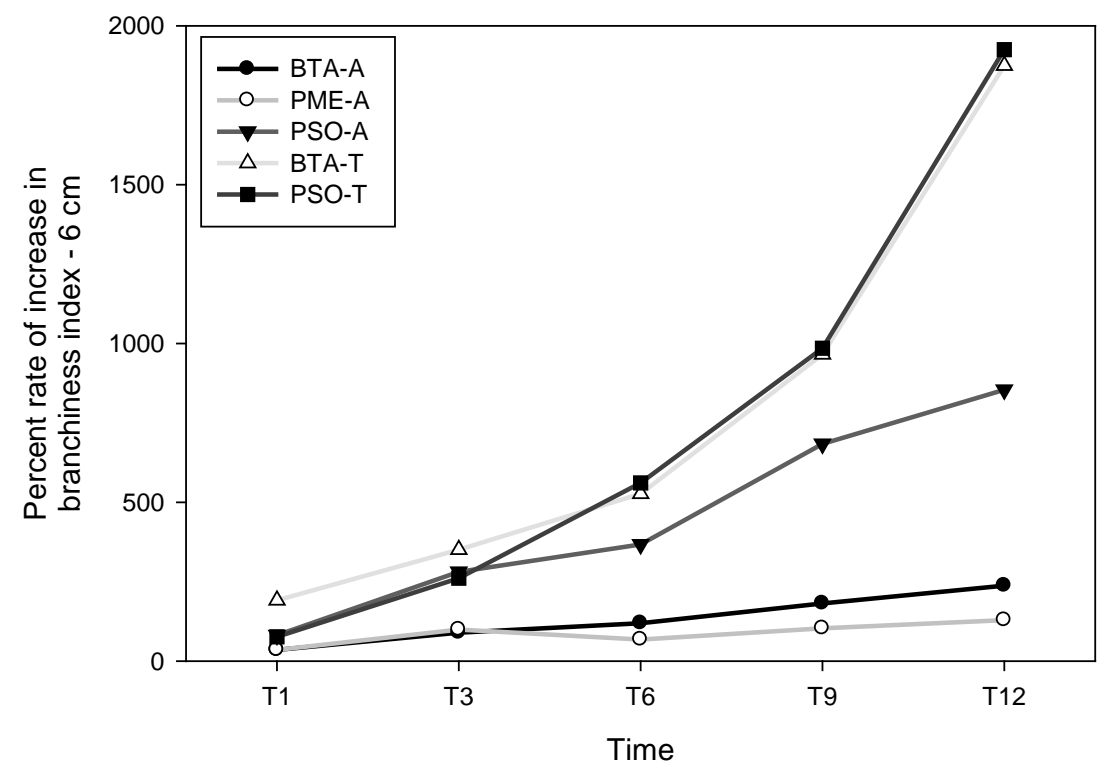

Figure 8. Percent rate of increase in branchiness index. 
[80]-[83]. Microsatellite markers used in this study were particularly successful in determining genetic differentiation in A. cervicornis colonies located within reef patches in scales smaller than $2 \mathrm{~km}^{2}$. Genetic differentiation in corals between reefs separated by a few kilometers is generally not significant, except when introgression of alleles is observed [39] [84] [85]. Such small-scale structure was recently evidenced in A. cervicornis using spatial autocorrelation of nuclear and mtDNA data [86]. Here, we also evidenced a similar small-scale structure suggesting that remnant A. cervicornis wild populations around Culebrita Island and Los Corchos reef system have a high genetic diversity per unit of area and can provide genetically diverse propagules for coral farming and reef rehabilitation efforts. Further, this suggests that high genetic diversity could be rapidly achieved collecting source fragments from relatively small spatial scales.

This study also confirmed that the original phenotypic pre-selection of wild coral samples for coral farming using low-tech traditional field identification of coral genetic clones by simple observation and comparison of source fragments showed a $90 \%$ coincidence with different genetic identity as confirmed through complex hightech laboratory testing. Therefore, experienced coral farmers can very certainly have the ability to select in the field different genetic clones within relative small spatial scales without having to conduct expensive state-ofthe-art genetic studies. This finding is very important as it validates traditional, low-tech, community-based methods for selecting coral clones in the field which will continue to be used in remote islands and in traditionallyunderserved communities which lack resources and high-tech tools.

\subsection{Extreme Rainfall and Poor Land Use Patterns Are a Major Threat for Coral Farms}

Extreme rainfall events and storm-associated rainfall, in combination with poor land uses, represented the most significant environmental threat to coral farming success in this study. It is paramount to consider the long-term environmental history of sites selected for coral farming and that of adjacent lands and watersheds during the planning stage of any proposed coral farming project. In our particular case, selected sites showed since 2003 outstanding environmental conditions in support of successful coral farming. But since 2011, there has been a major burst of tourism activities at BTA that has propelled increased traffic through a small local road parallel to the beach, resulting in an increased number of visitors, multiple recreational activities (i.e., charter vessels, kayaking, snorkeling, SCUBA diving), and from 100 to 250 visitors per day. This has also resulted in increased deforestation of land adjacent to the existing road for unpaved parking and areas for turning around public buses. There has been also a recent increase in deforestation of steep slopes at PME for the construction of access roads to private properties adjacent to the shoreline, which has resulted in increased turbid runoff pulses. Areas that have undergone significant alterations in land use patterns or that have undergone significant construction activities may not be suitable sites for coral farming projects as local watersheds can be largely vulnerable to major runoff events and erosion during extreme rainfall episodes. Extreme localized rainfall events have become a common phenomenon across regional to global scales over the last century [87] [88], and particularly across the Caribbean [89], as a typical manifestation of extreme weather events associated to increasing climate change impacts. Major variation in large-scale rainfall patterns [90] and sea surface warming trends across the region [91] have largely been associated to El Niño Southern Oscillation (ENSO) dynamics. Increasing hurricane frequency and severity across the Atlantic has been associated to sea surface warming trends [92]-[94]. There has also been a trend of increasing rainfall extremes associated to tropical storm and hurricane impacts, which may result in localized monthly rainfall anomalies of $+150 \%$ or higher [95], similar to extremes documented in this study. But the lack of long-term weather monitoring data and the lack of functional monitoring stations networks across multiple locations such as Culebra Island often result in weak spatial and temporal resolution of weather patterns on local scales, and in common failure to document impacts by extreme events. The observed pattern of extreme rainfall impacts through this study has largely coincided with recent trends of increasing SST across the northeastern Caribbean and mid-Atlantic regions [89] [90] [96]. When such events occur, high amounts of rainfall can impact relatively small, localized areas (i.e., individual watersheds) within a relatively short time span (i.e., from a few hours to about 24 - $48 \mathrm{hr}$ ). Under such conditions, runoff impacts on coastal waters of small tropical islands can be significant.

Extreme rainfall across waters adjacent to Puerto Rico ( $<20 \mathrm{~km}$ from Culebra Island) based on Doppler radar imagery through this study were significantly stronger than values recorded at a single rain gauge station over the island. Examples of these included a $31 \mathrm{~cm}$ rainfall event during a $24 \mathrm{hr}$ period (July 2-3, 2011) and a $78 \mathrm{~cm}$ maximum rainfall event associated to Hurricane Irene within approximately $60 \mathrm{hr}$ (August 21-24, 2011). There 
was also a $104 \mathrm{~cm}$ rainfall event over open sea adjacent to Culebra associated to tropical storm María within only $23 \mathrm{hr}$ (September 13, 2011). Overall, extreme rainfall measured with a rain gauge in Culebra Island during this study resulted in up to $127 \%$ to $215 \%$ monthly rainfall anomalies. But simultaneous Doppler estimates suggested up to $165 \%$ to $521 \%$ monthly anomalies for some locations across Culebra Island adjacent to coral farming sites, pointing out at the importance of significant small-scale spatial variability of extreme events.

Extreme weather events have also been shown to influence multiple ecosystems across global scales [97]. Rainfall rates $>2.5 \mathrm{~cm} / \mathrm{hr}$, in combination with impacts from soil erosion and sediment-laden, nutrient-loaded runoff, and with significant shifts in wind direction and velocity, and in ocean surface circulation can cause major localized shifts in water salinity, and in sediment, nutrients and microbes delivery to adjacent coral reefs. There is solid evidence that extreme rainfall and runoff pulse events can deliver significant concentrations of dissolved organic carbon (DOC) [98] and dissolved inorganic carbon (DIC) to recipient water bodies [99] [100], capable of locally altering water $\mathrm{pH}$ due to increased $\mathrm{CO}_{2}$ delivery [101]. We did not measure $\mathrm{pH}$ during this study, but mean $\mathrm{pH}$ across the study sites was determined in a previous study to be $8.24 \pm 0.02$ (95\% confidence interval) across a one year period of time [102]. There is also isotopic evidence of fluctuating impacts of rainfall events in Puerto Rico that show the marine origin of most of the rainfall across the northeastern Caribbean Region [103]. Isotopic analysis can also help elucidate long-term variability in regional rainfall patterns at regional scales [104], and could be a significant tool to quantify the magnitude of runoff impacts and LBSP on coral farming and reef rehabilitation efforts in the future.

Extreme events can have major rapid impacts on adjacent coral reefs communities, particularly on highly susceptible taxa such as Acroporid corals, often resulting in chronic alterations of coastal water quality [30] [33] [105], in localized coral mortality events [33] [106] [107], and in irreversible alterations of coral reef benthic community structure [31]. Therefore, besides major turbid runoff impacts on corals, extreme offshore rainfall events can also produce significant localized alterations of salinity close to the surface that, depending on oceanic surface currents and wind patterns, can further impact adjacent shallow reefs. Such events are predicted to increase with global warming trends [107] and the potential use of temporal variability in DOC/DIC pulses and in rainfall isotopic signals should be incorporated to address future impacts of extreme rainfall events on marine ecosystem dynamics and in coral outplanting success.

\subsection{Community-Based Coral Farming: A Race against Adversity}

Community-based coral farming efforts in Culebra have been highly successful since 2003 by reintroducing over 15,000 threatened Staghorn coral colonies back to local coral reefs, by maintaining multiple different storm-swell resistant structures, by restoring sexual reproduction potential on local reef scales, by fostering increased fish migration, recruitment and the creation of new essential fish habitats, by fostering fish spillover effects, and by demonstrating that under proper training and education, community-based volunteers can be highly successful in co-managing and recovering coral reef resources with minimal government intervention. This has happened in spite of the increase in illegal deforestation activities adjacent to coral farming sites over recent years, of uncontrolled recreational uses, of the limited support provided by government institutions to the project, and in spite of the weak institutional governance and political will to implement and enforce existing environmental regulations and the existing management plan of CLPNR.

The community-based adaptive shift from "A frames" to HLN units resulted in a major improvement of coral farming outcomes during the second year of the project, in spite of recurrent impacts by extreme rainfall events and storms. For instance, overall coral fragment survival during 2011-2012 in "A frames" improved from a global mean of $73 \%$ to $81 \%$ in 2012-2013. HLN units incorporated in 2012-2013 had a mean 97\% survival rate. These results are substantially higher than those previously documented in several studies elsewhere across the Caribbean, where very high method-specific colony mortality occurred across several locations (Table 3). Percent tissue cover averaged 91\% in "A frames" during 2011-2012, and 86\% during 2012-2013, but improved to 98\% in HLN units in 2012-2013. Total fragment length in “A frames” during 2011-2012 averaged $26.9 \mathrm{~cm} / \mathrm{y}$ and $27.0 \mathrm{~cm} / \mathrm{y}$ in 2012-2013, but improved to $40.0 \mathrm{~cm} / \mathrm{y}$ in HLN units in 2012-2013. These results compared favorably with colony growth rates reported from similar coral farming efforts in the literature (Table 3) and from colony growth rates in the wild (Table 4). Fragment growth rates in "A frame" units in this study was 50\% to 545\% faster than that reported from coral farming efforts in Florida and 17\% more than that documented in Jamaica. But fragment growth rates in HLN units in this study was $122 \%$ to $857 \%$ faster than that reported from coral 
Table 3. Summary of A. cervicornis skeletal extension and survival rates measured on coral farms.

\begin{tabular}{|c|c|c|c|c|c|}
\hline Location & Time (m) & Skeletal extension (cm/y) & Method & Coral mortality & Reference \\
\hline Jamaica & 13 & 23.0 & A frame & $31 \%-100 \%$ & [108] \\
\hline Florida, USA & 4 & $4.18-18.0$ & Lattice & 17\% (2 months) & [109] \\
\hline Florida, USA & 20 days & $5.4-7.6$ & Cinder blocks & $\begin{array}{l}87 \%(2.5 \mathrm{~cm} \text { size }) \\
13 \%(3.5 \mathrm{~cm} \text { size })\end{array}$ & [110] \\
\hline La Parguera, PR & 3 & - & A frame & $2.5 \%$ & [46] \\
\hline Guayanilla, PR & 12 & - & Nails, epoxy & $12 \%$ & [57] \\
\hline Guayanilla, PR & 12 & 52.5 & FUCA $^{*}$ & $2.6 \%-12.5 \%$ & [56] \\
\hline Culebra, PR & $\begin{array}{l}12(\mathrm{Y} 1) \\
12(\mathrm{Y} 2)\end{array}$ & $\begin{array}{l}15.4-37.0(\mathrm{Y} 1) \\
21.3-49.7(\mathrm{Y} 2)\end{array}$ & $\begin{array}{l}\text { A frame } \\
\text { HLN }\end{array}$ & $\begin{array}{l}16 \% \text { - 43\% (Y1, hurricane) } \\
0.4 \%-20.9 \% \text { (Y2, storms) }\end{array}$ & This study \\
\hline
\end{tabular}

${ }^{*}$ FUCA = floating underwater coral array.

Table 4. Summary of A. cervicornis skeletal extension rates measured on wild colonies.

\begin{tabular}{ccc}
\hline Location & Mean skeletal extension $(\mathrm{cm} / \mathrm{y})$ & Reference \\
\hline Buck Island, USVI & 7.1 & {$[111]$} \\
Buck Island, USVI & 10.0 & {$[112]$} \\
Florida, USA & 4.5 & {$[113]$} \\
Florida, USA & 11.0 & {$[114]$} \\
Florida, USA & 4.5 & {$[115]$} \\
Florida, USA & 12 & {$[36]$} \\
Barbados & 14.6 & {$[116]$} \\
Jamaica & 26.6 & {$[116]$} \\
Jamaica & 12.0 & {$[37]$} \\
Jamaica & 11.06 (backreef) & {$[117]$} \\
La Parguera, PR & 4.35 (pinacle) & {$[118]$} \\
La Parguera, PR & 7.8 & [119] \\
Culebra, PR & 10.6 (backreef) & Hernández-Delgado \\
& 14.7 (forereef) & (unpub. data) \\
\hline
\end{tabular}

*Data from 2-year-old outplants; ${ }^{* *}$ Data from 3-year-old outplants.

farming efforts in Florida and 74\% more than that documented in Jamaica. Acropora cervicornis mean growth rate in the wild is about $10.66 \mathrm{~cm} / \mathrm{y}$, but has been observed to reach values of up to 41 to $55 \mathrm{~cm} / \mathrm{yr}$ on 2-year-old outplanted colonies, and of up to 41 to $77 \mathrm{~cm} / \mathrm{yr}$ on 3-year-old outplanted colonies in Culebra Island following previous coral farming efforts. These observations are consistent with previous studies from Guayanilla, Puerto Rico, where growth rates of $52 \mathrm{~cm} / \mathrm{y}$ were documented [56].

Colony growth on "A frames" was 153\% faster than the Caribbean wide mean in the wild. Growth rate on HLN units was $275 \%$ faster than that in the wild. The rate of increase in branch abundance per colony was also outstanding, although there is no data in the literature to establish comparisons. These results suggest that community-based low-tech adaptation of coral farming methods used in this study resulted in improved coral colony 
survival rates, percent tissue cover, linear skeletal extension, increased branch production, and in increased production of harvestable branches, in spite of continued adverse impacts from extreme rainfall and runoff events, and from storm-related wave action. But recent disturbing evidence suggests that fast skeletal extension rates may not necessarily reflect healthy coral reef conditions. Elevated symbiotic respiration rates as a result of chronic enlarged Symbiodinium populations and year-round elevated SST can result in significantly enhanced skeletal extension rates in corals [120]. In turn, such elevated respiration rates can reduce the photosynthesis: respiration ratio of symbionts, restricting the capacity of the coral host to maintain sufficient and sustainable levels of energy reserves (i.e., lipids) needed to sustain their essential functions (i.e., homeostasis, tissue repair ability, mucous production, immune functions, sexual reproduction, biophysical stress resistance). Therefore, increasing coral skeletal extension rates should be interpreted with caution as it could be implying unequivocal combined impacts from increased LBSP and climate change, and may significantly limit the ability of corals to withstand and recover from disturbance. This aspect should be carefully studied.

\subsection{Community-Based Participation: A Key for Successful Coral Reef Rehabilitation}

Community-based participation in this project, in direct collaboration with academic resources, continued being fundamental for the success of the Community-Based Coral Aquaculture and Reef Rehabilitation Program since 2003 [55]. Community-based participation and project engagement was critical in five ways: 1) It was important to strengthen community-based participants theoretical, technical, and hands-on training and education in coral farming, and reef conservation and restoration methods in support to the management of the local MPA; 2) Strengthen the existing community-based emergency rapid response team capable of rapidly providing technical assistance to local government institutions on emergency reef restoration efforts (i.e., after hurricane or tropical storm impacts; or after vessel grounding incidents); 3) Improved the preventive management and maintenance of coral farming units by trained community-based volunteers to reduce impacts from storm swell generated damage to near zero in both, coral farming units and outplanted colonies. Regular maintenance was also important to maintain the structural integrity of farming units and to reduce impacts from potential competing taxa (i.e., macroalgae, sponges, hydroids, fire corals) and to remove coral predators (i.e., gastropods, fireworms); 4) This project further confirmed our decadal-long experience that community-based participation and engagement is a critically successful behavior-transforming outreach and educational tool; and 5) Strengthening and empowering base communities to improve their problem analysis and decision-making tools regarding managing their adjacent shallow coral reef ecosystems that constitute their first line of defense against storm swells and sea level rise.

Nonetheless, reciprocal feedback from government institutions was lacking most of the time, providing very limited support, in particular, a very weak enforcement of existing no-fishing regulations within the no-take MPA. There was also no enforcement at all regarding LBSP, deforestation of adjacent lands, and the implementation of mandatory erosion and sedimentation control measures. Weak governance and natural resource management failures have been previously identified as key roadblocks to the successful conservation of coastal resources in Puerto Rico [33] [121]. Weak governance can be a major roadblock to MPA, coral farming and reef rehabilitation success, and deserves major attention. A particular concern has also been the recent burst in dubious political decisions favoring zoning changes and private development in highly sensitive areas on very steep slopes prone to erosion and in lands adjacent to the shoreline through fast-tracked permits, which halt public scrutiny. Fast-tracked permitting procedures often lack full evaluation of environmental impacts and have resulted in non-sustainable development practices with strong adverse impacts in small tropical islands [69].

\subsection{Timing of Coral Farming Activities Is Critical for Project's Success}

Project timing and phasing on funding agencies is often never coupled with the appropriate environmental conditions needed for successful coral propagation. It is critical that coral farming projects start during cooler months (Winter to Spring) and this must be stressed out to funding and regulatory agencies when planning funding and reporting cycles for such projects. Coral transplanting during summer or fall should be avoided to reduce or prevent coral mortality and the probability of failure due to high SST stress, runoff impacts, or potential disease outbreaks. Most coral species are also completing their gametogenesis cycle during the warmer months, which require strong energy expenditure and may further compromise their survival if fragmenting and transplanting is conducted before mass spawning occurs. 


\subsection{The Role of No-Take MPAs: A Matter of Political Will}

No-take MPAs are often established to protect and help recover reef fish stocks, as well as to restore herbivorous fish guilds, from fishing impacts [122]. Increased herbivory can reduce algal cover inside MPAs [123] and has been shown to be important for recovering coral reef ecosystem resilience by fostering increased coral growth [124] [125]. But it has been suggested that the Wider Caribbean Region has a higher vulnerability to climate change impacts due to its lower resilience, faster rates of macroalgal growth, higher rates of algal recruitment, basin-wide iron-enrichment of algal growth from aeolian dust, lack of Acroporid corals, lower herbivore biomass and missing groups of herbivores, in comparison to Indo-Pacific coral reefs [126]. Lack of coral and fish functional redundancy of Caribbean reefs can also increase its long-term vulnerability to climate change and ocean acidification impacts [127]. This may suggest that even the establishment of fully functional MPAs could have only a limited impact on coral reef recovery unless policy makers confront the accelerating negative effects of the global-scale sources of coral mortality [123]. There is mounting evidence that even coral reefs located within no-take MPAs are rapidly declining [63] [64] [71] [128]. Unequivocally, these trends point out at the need of vigorously implementing integrated management strategies that support reef resilience, complemented by strong policy decisions [129], to reduce the rate of impacts associated to multiple local human-driven factors and climate change. But such integration requires strong, management-oriented, novel scientific supporting research with a strong community-based integrative and participatory approach. This is where community-based coral farming and reef rehabilitation efforts become critical to improve no-take MPA success.

In this study, the no-take CLPNR resulted in no significant improvement of coral farming success due to rapidly changing land use and recreational use patterns adjacent to BTA site. Coral survival rates, percent live tissue cover and colony growth always resulted higher at non-MPA control site PSO. There has been a dramatic increase since 2011 in site visits at BTA by tourists either from beach access, kayaking, jet skiing or from charter vessels. Coral outplanting activities to natural reef bottoms within the reserve have resulted in a significant aesthetic improvement of the local sheltered coral reefs and in a significant increase in fish diversity, abundance and biomass, and in the abundance of endangered green turtles (Chelonia mydas), an impact that has not been reached yet at the non-reserve control site. This suggests that no-take MPAs, in combination with coral farming and outplanting, can be highly successful to improve overall reef resilience. But concomitantly, successful reef rehabilitation has also fostered an interest to visit the reef, resulting in a net increase in the number of visitors, and in increased traffic and road widening near BTA. This has exposed multiple areas to soil erosion, which has in turn resulted in dramatic increases in runoff impacts. Sediment delivery has been identified as a major threat for nearshore coral reef ecosystems in Culebra [130]. There was already a successful implementation of runoff controls through community-based efforts, with the collaboration of government agencies [131]. But these measures have not been enough as governance and enforcement still remain weak. An example of such weakness is that by the end of the study period, primary cacti forests across steep lands adjacent to the non-MPA control coral farming site at PSO were also being fully deforested by local residents with the support of the local government to allow illegal invasions of public lands to establish permanent camping grounds for weekend enjoyment of local residents. This now represents a major unprecedented threat of potential sediment-laden runoff impacts similar to that of PME and BTA. Coral farms originally established at PME (within the CLPNR) during the first year of the project had to be relocated due to excessive pulse runoff impacts. Runoff impacts dramatically increased during the project at BTA as well, and now runoff is becoming a major threat at PSO, but no preventive or remedial action from government institutions have been implemented yet. Therefore, ignoring the reality of chronic environmental degradation and the total lack of political will to enforce existing zoning and environmental regulations constitute also a major roadblock to success.

There is still a need to incorporate stronger management and enforcement measures to the existing management plan of the CLPNR to further reduce such adverse impacts and to regulate impacts from recreational activities. But also there is still a need to review, update and fully implement a science-based land use management plan to reduce impacts of LBSP and inappropriate land uses on adjacent coastal ecosystems. Coral farming and reef rehabilitation success will largely depend upon strong governance, and successful management and enforcement of adjacent land uses and recreational activities. There is also a major need to link ecological resilience to governance structures, economics and society in order to successfully and sustainably manage and rehabilitate marine ecosystems [132]. Failing to recognize that reality could also represent a major roadblock for successful conservation and management through a sustainable participatory process. 


\section{Conclusions}

Community-based, low-tech coral aquaculture approaches used in this study proved to be successful, reliable and highly cost-effective tools to conserve and restore threatened Staghorn coral populations with minimum intervention and maintenance, and generated multiple management-oriented lessons learned. The CommunityBased Coral Aquaculture and Reef Rehabilitation Program has continued to be a successful model to empower wider Caribbean community stakeholders to implement basic coral reef conservation and coral transplanting methods. This could have major implications in helping base communities engage into conservation-oriented coral reef management activities, and to help communities adapt and manage climate change impacts on their "backyard" coral reef ecosystems. Hands-on, behavior-modifying, transformative education continued to be a crucial product of community integration and active participation, improving local stewardship, and fostering their successful integration into planning, decision-making processes, and in the implementation of local-based coral reef and fisheries conservation-oriented and restoration-oriented management. However, rapid adaptive responses in low-tech coral farming and reef rehabilitation will become critical to keep up with climate change impacts in the near future. Community-based efforts will continue to be fundamental to successfully foster the rehabilitation of reef ecosystem's resilience, biodiversity, ecological functions, and its socio-economic, ecological and environmental benefits and services. Further, the integration of the academia, NGOs, fisher communities, base communities, private stakeholders and government institutions has become a successful collaborative model that can be applied through the wider Caribbean Region and will be important in a time of economic constraints across developing island nations.

Nonetheless, there is a particular concern with the still prevailing lack of adaptation capacity of multiple coastal base communities to climate change impacts, including sea level rise and loss of coral reefs, across many small island nations through the wider Caribbean, which could affect the sustainability of coastal community livelihoods [69]. Further, weak governance and lack of political will to enforce existing regulations can be a major deterrant of community compliance and a roadblock to project success. This points out at the importance of coral reef rehabilitation to foster increased coral reef ecosystem resilience, functions, and services, further improving the adaptability of coastal communities and coral reef ecosystems to climate change. A concerning call for precaution is also brought up by documented coral skeletal extension rates in this study, as well as in some recent studies of A. cervicornis farming [56], as it could be the result of successful methodologies being used, but may also imply significant combined impacts from increased LBSP and climate change which may significantly compromise coral colonies ability to withstand disturbance and may explain significant recurrent mortality episodes from multiple disturbance events.

It is not clear whether we can foster acclimatization responses in coral reefs to futures characterized by recurrent ecological surprises, non-linear change and unexpected long-term consequences of climate change and ocean acidification. The speed at which climate change is impacting reef ecosystems leaves little opportunity for evolutionary processes to come to the aid of corals and other reef inhabitants, thus survival will be highly dependent upon any natural resistance already existing in the gene pools today [66]. It will also rely upon successful governance, management of reef resources and land use patterns, and upon consistent enforcement of existing environmental regulations. Therefore, the identification of high-temperature resistant genetic clones has become a critical tool for successful coral propagation and reef restoration [133]. On that line, we were successfully able to identify, propagate and restock local depleted populations using six different shallow-water genetic clones of A. cervicornis highly resistant to existing warm surface water conditions. But efforts should also be implemented to propagate deepwater genetic clones across deepwater habitats to improve ecological scales of connectivity across multiple spatial scales.

Rehabilitated coral reefs are part of a human-coupled ecosystem. The most important challenge or potential roadblock to future progress of coral farming and reef rehabilitation overall is largely related to climate changeassociated conditions, in combination with poor land use management and weak governance. Therefore, human activities must be integrated into the equation for coral farming and reef rehabilitation success. Environmental history, ecological trajectory and ecosystem conditions are critical factors for any coral propagation success. This suggests that positioning of coral farms is fundamental. Special considerations should be given to factors such as: 1) environmental history of each proposed coral farming site; 2) environmental conditions of adjacent reef communities; 3) sediment movement (i.e., bedload, sedimentation rates); 4) distance of sources of runoff; 5) exposure to wave action, winter storm and hurricane swells; 6) distance to large sand deposits (risk from 
sediment bedload and sandblasting during bottom swells and storms); and 7) magnitude and extent of recreational activities impacting the system, even with so called "low-impact" activities. Therefore, carrying capacity and the limit of acceptable change need to be determined for such sites.

Successful coral farming and reef rehabilitation will also require functional synchronized and integrated management efforts to address land use patterns, water quality issues and fishing activities (to improve herbivore fish guilds) in order to improve ecosystem conditions for enhancing coral and fish recruitment, and overall biodiversity recovery [127]. It will be critical to fully implement LBSP controls, as well as appropriate watershed-scale management plans to control runoff impacts. Runoff-associated bleaching events and colony mortality can be highly clone-specific, as well as site-specific and event-specific. No generalizations can be made because not all coral clones respond the same, or because impacts from any given extreme rainfall event can produce different impacts on different locations, and on different times of the year. The combination of high SST and factors such as meso-scale water quality (i.e., from gyre currents) can also have significant impacts on project outcomes and should be closely monitored. Achieving successful local management of reefs is vital to maintain the sustained net production of coral farms, and of reef structure, and therefore the provision of the important ecosystem services that they provide. These measures are also vital for buying time for reefs while global action on climate change is implemented [61]. Any problem or imbalance in any of these elements will have in the long run a negative impact on rehabilitation success. If such impacts occur in combination with increasing forecasted climate change-related negative impacts in the near future and increased reef degradation rates, they could make community-based coral reef rehabilitation more challenging. In combination with declining reef condition and increased inability of coral and fish larvae to identify suitable natural reef bottoms for settlement [134], it could potentially drive rapidly declining, transient coral reefs into the slippery slope to slime [135].

\section{Acknowledgements}

This work was possible thanks to funding provided by the National Oceanic and Atmospheric Administration (NOAA) Restoration Center and The Nature Conservancy to Sociedad Ambiente Marino (MAR-SAM-110110). Partial support was also provided by the National Science Foundation (HRD \#0734826) through the Center for Applied Tropical Ecology and Conservation (CATEC), and the University of Puerto Rico's Central Administration to E. A. Hernández-Delgado. Publication costs were covered by the University of Puerto Rico's Sea Grant College Program. Activities were conducted under permits 2010-IC-041, 2012-IC-019, and 2013-IC-054 provided by the PR Department of Natural and Environmental Resources. Thanks to W. Kunke for providing access to his personal records of daily rainfall data from Culebra Island. We appreciate all field support provided by A. Archilla, G. Cabrera-Beauchamp, E. González, M. C. López, J. L. Medina-Muñiz, J. Murcia, J. Nifosi, B. J. Rosado-Matías, and multiple other volunteers from local communities and from Sociedad Ambiente Marino's Students Chapter (CESAM). This publication is a contribution from CATEC's Coral Reef Research Group and SAM's collaborative Coral Reefs Conservation and Rehabilitation Project.

\section{References}

[1] Hughes, T.P. (1994) Catastrophes, Phase Shifts and Large-Scale Degradation of a Caribbean Coral Reef. Science, 265, 1547-1551. http://dx.doi.org/10.1126/science.265.5178.1547

[2] McClanahan, T.R. and Muthiga, N.A. (1998) An Ecological Shift in a Remote Coral Atoll of Belize over 25 Years. Environmental Conservation, 25, 122-130. http://dx.doi.org/10.1017/S0376892998000174

[3] Gardner, T.A., Côté, I.M., Gill, J.A., Grant, A. and Watkinson, A.R. (2003) Long-Term Region-Wide Declines in Caribbean Corals. Science, 301, 958-960. http://dx.doi.org/10.1126/science.1086050

[4] Bruckner, A.W. and Hourigan, T.F. (2000) Proactive Management for Conservation of Acropora palmata: Application of the US Endangered Species Act. Proceedings of the 9th International Coral Reef Symposium, 2, 661-665.

[5] Aronson, R.B. and Precht, W.F. (2001) White-Band Disease and the Changing Face of Caribbean Coral Reefs. Hydrobiologia, 460, 25-38. http://dx.doi.org/10.1023/A:1013103928980

[6] Bruckner, A.W. (2002) Proceedings of the Caribbean Acropora Workshop: Potential Application of the US Endangered Species Act as a Conservation Strategy. NOAA Tech. Memorandum NMFS-OPR-24, Silver Spring, 199 p.

[7] Wapnick, C.M., Precht, W.F. and Aronson, R.B. (2004) Millennial-Scale Dynamics of Staghorn Coral in Discovery Bay, Jamaica. Ecology Letters, 7, 354-361. http://dx.doi.org/10.1111/j.1461-0248.2004.00586.x 
[8] Hernández-Delgado, E.A. (2000) Effects of Anthropogenic Stress Gradients in the Structure of Coral Reef Epibenthic and Fish Communities. Ph.D. Dissertation, Department of Biology, University of Puerto Rico, San Juan, 330 p.

[9] Weil, E., Hernández-Delgado, E., Bruckner, A., Ortiz, A., Nemeth, M. and Ruiz, H. (2002) Distribution and Status of Acroporid Coral (Scleractinia) Populations in Puerto Rico. In: Bruckner, A.W., Ed., Proceedings of the Caribbean Acropora Workshop: Potential Application of the U.S. Endangered Species Act as a Conservation Strategy, NOAA Tech. Memorandum NMFS-OPR-24, Silver Spring, 71-98.

[10] Goreau, T.F. (1959) The Ecology of Jamaican Coral Reefs I. Species Composition and Zonation. Ecology, 40, 67-90. http://dx.doi.org/10.2307/1929924

[11] Milliman, J.D. (1973) Caribbean Coral Reefs. In: Jones, O.A. and Endean, R., Eds., Biology and Geology of Coral Reefs, Vol. 1: Geology 1, Academic Press, New York, 1-50.

[12] Geister, J. (1977) The Influence of Wave Exposure on the Ecological Zonation of Caribbean Coral Reefs. Proceedings of the 3rd International Coral Reef Symposium, 1, 23-29.

[13] Mesolella, K.J. (1967) Zonation of Uplifted Pleistocene Coral Reefs on Barbados, West Indies. Science, 156, 638-640. http://dx.doi.org/10.1126/science.156.3775.638

[14] Greenstein, B.J., Curran, H.A. and Pandolfi, J.M. (1998) Shifting Ecological Baselines and the Demise of Acropora cervicornis in the Western North Atlantic and Caribbean Province: A Pleistocene Perspective. Coral Reefs, 17, 249261. http://dx.doi.org/10.1007/s003380050125

[15] Pandolfi, J. (1999) Response of Pleistocene Coral Reefs to Environmental Change over Long Temporal Scales. American Zoologist, 39, 113-130.

[16] Pandolfi, J. (2002) Coral Community Dynamics at Multiple Scales. Coral Reefs, 21, 13-23. http://dx.doi.org/10.1007/s00338-001-0204-7

[17] Pandolfi, J. and Jackson, J.B.C. (2001) Community Structure of Pleistocene Coral Reefs of Curaçao, Netherland Antilles. Ecological Monographs, 71, 49-67.

[18] Budd, A.F., Petersen, R.A. and McNeill, D.F. (1998) Stepwise Faunal Change during Evolutionary Turnover: A Case Study from the Neogene of Curaçao, Netherlands Antilles. PALAIOS, 13, 170-188. http://dx.doi.org/10.2307/3515488

[19] Budd, A.F., Stemann, T.A. and Johnson, K.G. (1994) Stratigraphic Distributions of Genera and Species of Neogene to Recent Caribbean Reef Corals. Journal of Paleontology, 68, 951-977.

[20] Pandolfi, J. and Jackson, J.B.C. (2006) Ecological Persistence Interrupted in Caribbean Coral Reefs. Ecology Letters, 9, 818-826. http://dx.doi.org/10.1111/j.1461-0248.2006.00933.x

[21] Greer, L., Jackson, J.E., Curran, H.A., Guilderson, T. and Teneva, L. (2009) How Vulnerable Is Acropora cervicornis to Environmental Change? Lessons from the Early to Middle Holocene. Geology, 37, 263-266. http://dx.doi.org/10.1130/G25479A.1

[22] Williams, D.E. and Miller, M.W. (2005) Coral Disease Outbreak: Pattern, Prevalence and Transmission in Acropora cervicornis. Marine Ecology Progress Series, 301, 119-128. http://dx.doi.org/10.3354/meps301119

[23] Vollmer, S.V. and Kline, D.I. (2008) Natural Disease Resistance in Threatened Staghorn Corals. PLoS ONE, 3, e3718. http://dx.doi.org/10.1371/journal.pone.0003718

[24] Casas, V., Kline, D.I., Wegley, L., Yu, Y., Breltbart, M. and Rohwer, F. (2004) Widespread Association of a Rickettsiales-Like Bacterium with Reef-Building Corals. Environmental Microbiology, 6, 1137-1148. http://dx.doi.org/10.1111/j.1462-2920.2004.00647.x

[25] Kline, D.I. and Vollmer, S.V. (2011) White Band Disease (Type I) of Endangered Caribbean Acroporid Corals Is Caused by Pathogenic Bacteria. Scientific Reports, 1. http://dx.doi.org/10.1038/srep00007

[26] Stoddart, D.R. (1963) Effects of Hurricane Hattie on the British Honduras Reefs and Cays, October 30-31, 1961. Atoll Research Bulletin, 95, 1-142. http://dx.doi.org/10.5479/si.00775630.95.1

[27] Stoddart, D.R. (1969) Ecology and Morphology of Recent Coral Reefs. Biological Reviews, 44, 433-498. http://dx.doi.org/10.1111/j.1469-185X.1969.tb00609.x

[28] Stoddart, D.R. (1974) Post-Hurricane Changes on the British Honduras Reefs: Res-Survey of 1972. Proceedings of the 2nd International Coral Reef Symposium, 2, 473-483.

[29] Ball, M.M., Shinn, E.A. and Stockman, K.W. (1967) The Geologic Effects of Hurricane Donna in South Florida. The Journal of Geology, 75, 583-597. http://dx.doi.org/10.1086/627283

[30] Bonkosky, M., Hernández-Delgado, E.A., Sandoz, B., Robledo, I.E., Norat-Ramírez, J. and Mattei, H. (2009) Detection of Spatial Fluctuations of Non-Point Source Fecal Pollution in Coral Reef Surrounding Waters in Southwestern Puerto Rico Using PCR-Based Assays. Marine Pollution Bulletin, 58, 45-54.

http://dx.doi.org/10.1016/j.marpolbul.2008.09.008 
[31] Hernández-Delgado, E.A., Sandoz, B., Bonkosky, M., Mattei, H. and Norat, J. (2008) Impacts of Non-Point Source Sewage Pollution in Elkhorn Coral, Acropora palmata (Lamarck), Assemblages of the Southwestern Puerto Rico Shelf. Proceedings of the 11th International Coral Reefs Symposium, Fort Lauderdale, 7-11 July 2008, 747-751.

[32] Hernández-Delgado, E.A., Hutchinson-Delgado, Y.M., Laureano, R., Hernández-Pacheco, R., Ruiz-Maldonado, T.M., Oms, J. and Díaz, P.L. (2011) Sediment Stress, Water Turbidity and Sewage Impacts on Threatened Elkhorn Coral (Acropora palmata) Stands at Vega Baja, Puerto Rico. Proceedings of the Gulf and Caribbean Fisheries Institute, 63, 83-92.

[33] Díaz-Ortega, G. and Hernández-Delgado, E.A. (2014) Land-Based Source Pollution in a Climate of Change: A Roadblock to the Conservation and Recovery of Elkhorn Coral Acropora palmata (Lamarck 1816). Natural Resources, 5, 561-581. http://dx.doi.org/10.4236/nr.2014.510050

[34] Renegar, D.A. and Riegl, B.M. (2005) Effect of Nutrient Enrichment and Elevated $\mathrm{CO}_{2}$ Partial Pressure on Growth Rate of Atlantic Scleractinian Coral Acropora cervicornis. Marine Ecology Progress Series, 293, 69-76. http://dx.doi.org/10.3354/meps293069

[35] Gilmore, M.D. and Hall, B.R. (1976) Life History, Growth Habits and Constructional Roles of Acropora cervicornis in the Patch Reef Environment. Journal of Sedimentary Petrology, 46, 519-522.

[36] Shinn, E. (1976) Coral Reef Recovery in Florida and the Persian Gulf. Environmental Geology, 1, 241-254. http://dx.doi.org/10.1007/BF02407510

[37] Tunnicliffe, V. (1981) Breakage and Propagation of the Stony Coral Acropora cervicornis. Proceedings of the National Academy of Sciences of the United States of America, 78, 2427-2431. http://dx.doi.org/10.1073/pnas.78.4.2427

[38] Highsmith, R.C. (1982) Reproduction by Fragmentation in Corals. Marine Ecology Progress Series, 7, 207-226. http://dx.doi.org/10.3354/meps007207

[39] García-Reyes, J. and Schizas, N.V. (2010) No Two Reefs Are Created Equal: Fine-Scale Population Structure in the Threatened Coral Species Acropora palmata and A. cervicornis. Aquatic Biology, 10, 69-83. http://dx.doi.org/10.3354/ab00254

[40] Rogers, C.S., Fitz III, H.C., Gilnack, M., Beets, J. and Hardin, J. (1984) Scleractinian Coral Recruitment Patterns at Salt River Submarine Canyon, St. Croix, US Virgin Islands. Coral Reefs, 3, 69-76. http://dx.doi.org/10.1007/BF00263756

[41] Irizarry-Soto, E. and Weil, E. (2009) Spatial and Temporal Variability in Juvenile Coral Densities, Survivorship and Recruitment in La Parguera, Southwestern Puerto Rico. Caribbean Journal of Science, 45, 269-281.

[42] Hernández-Delgado, E.A., González-Ramos, C.M. and Alejandro-Camis, P.J. (2014) Large-Scale Coral Recruitment Patterns in Mona Island, Puerto Rico: Evidence of Shifting Coral Community Trajectory after Massive Bleaching and Mortality. Revista de Biología Tropical, 62, 49-64.

[43] Mumby, P.J. (1999) Bleaching and Hurricane Disturbances to Populations of Coral Recruits in Belize. Marine Ecology Progress Series, 190, 27-35. http://dx.doi.org/10.3354/meps190027

[44] Guzmán, H.M. (1991) Restoration of Coral Reefs in Pacific Costa Rica. Conservation Biology, 5, 189-195. http://dx.doi.org/10.1111/j.1523-1739.1991.tb00123.x

[45] Bowden-Kerby, A. (1997) Coral Transplantation in Sheltered Habitats Using Unattached Fragments and Cultured Colonies. Proceedings of the 8th International Coral Reef Symposium, 2, 2063-2068.

[46] Bowden-Kerby, A. (2010) Restoration of Threatened Acropora cervicornis Corals: Intraspecific Variation as a Factor in Mortality, Growth and Self-Attachment. Proceedings of the 11th International Coral Reef Symposium, Session No. 24, 1-5.

[47] Fox, H.E., Pet, J.S., Dahuri, R. and Caldwell, R.L. (2000) Coral Reef Restoration after Blast Fishing in Indonesia. Proceedings of the 9th International Coral Reef Symposium, 2, 969-975.

[48] Fox, H.E., Mous, P.J., Pet, J.S., Muljadi, A.H. and Caldwell, R.L. (2006) Experimental Assessment of Coral Reef Rehabilitation Following Blast Fishing. Conservation Biology, 19, 98-107. http://dx.doi.org/10.1111/j.1523-1739.2005.00261.x

[49] Jaap, W.C. (2000) Coral Reef Restoration. Ecological Engineering, 15, 345-364. http://dx.doi.org/10.1016/S0925-8574(00)00085-9

[50] Precht, W.F. and Robbart, M. (2006) Coral Reef Restoration: The Rehabilitation of an Ecosystem under Siege. In: Precht, W.F., Ed., Coral Reef Restoration Handbook, CRC Press, Boca Raton, 1-24. http://dx.doi.org/10.1201/9781420003796.ch1

[51] Shaish, L., Levy, G., Katzir, G. and Rinkevich, B. (2010) Employing a Highly Fragmented, Weedy Coral Species in Reef Restoration. Ecological Engineering, 36, 1424-1432. http://dx.doi.org/10.1016/j.ecoleng.2010.06.022

[52] Bongiorni, L., Giovanelli, D., Rinkevich, B., Pusceddu, A., Chou, L.M. and Danovaro, R. (2011) First Step in the Res- 
toration of a Highly Degraded Coral Reef (Singapore) by in Situ Coral Intensive Farming. Aquaculture, 322-323, 191200. http://dx.doi.org/10.1016/j.aquaculture.2011.09.024

[53] Rinkevich, B. (2014) Rebuilding Coral Reefs: Does Active Reef Restoration Lead to Sustainable Reefs? Current Opinion in Environmental Sustainability, 7, 28-36. http://dx.doi.org/10.1016/j.cosust.2013.11.018

[54] Young, C.N., Shopmeyer, S.A. and Lirman, D. (2012) A Review of Reef Restoration and Coral Propagation Using the Threatened Genus Acropora in the Caribbean and Western Atlantic. Bulletin of Marine Science, 88, 1075-1098. http://dx.doi.org/10.5343/bms.2011.1143

[55] Hernández-Delgado, E.A. and Suleimán-Ramos, S.E. (2014) E.S.A. Coral Species Listing: A Roadblock to Community-Based Engagement in Coral Reef Conservation and Rehabilitation across the US Caribbean? Reef Encounter, 29, 11-15.

[56] Griffin, S., Spathias, H., Moore, T.D., Baums, I. and Griffin, B.A. (2012) Scaling up Acropora Nurseries in the Caribbean and Improving Techniques. Proceedings of the 12th International Coral Reef Symposium, 20A Restoration of Coral Reefs, 1-5.

[57] Hollarsmith, J.A., Griffin, S.P. and Moore, T.D. (2012) Success of Out-Planted Acropora cervicornis Colonies in Reef Restoration. Proceedings of the 12th International Coral Reef Symposium, 20A Restoration of Coral Reefs, 1-5.

[58] Hernández-Delgado, E.A., Suleimán, S. and Olivo, I. (2008) Low-Tech Ecological Rehabilitation of Bombarded Coral Reefs. Technical Report Submitted to the US Fish and Wildlife Service, Coastal Program, Boquerón, 29 September 2008, 42 p.

[59] Hernández-Delgado, E.A., Suleimán, S., Olivo, I., Fonseca, J. and Lucking, M.A. (2011) Alternativas de Baja Tecnología para la Rehabilitación de los Arrecifes de Coral. In: Seguinot-Barbosa, J., Ed., Islas en Extinción: Impactos Ambientales en las Islas de Puerto Rico, Ediciones SM, Cataño, 178-186.

[60] Mumby, P.J. and Steneck, R.S. (2008) Coral Reef Management and Conservation in Light of Rapidly Evolving Ecological Paradigms. Trends in Ecology and Evolution, 23, 555-563. http://dx.doi.org/10.1016/j.tree.2008.06.011

[61] Hughes, T.P., Linares, C., Dakos, V., van de Leemput, I.A. and van Nes, E.H. (2013) Living Dangerously on Borrowed Time during Slow, Unrecognized Regime Shifts. Trends in Ecology and Evolution, 28, 149-155. http://dx.doi.org/10.1016/j.tree.2012.08.022

[62] Hoegh-Guldberg, O. (1999) Climate Change, Coral Bleaching and the Future of the World's Coral Reefs. Marine and Freshwater Research, 50, 839-866. http://dx.doi.org/10.1071/MF99078

[63] Edmunds, P.J. (2013) Decadal-Scale Changes in the Community Structure of Coral Reefs of St. John, US Virgin Islands. Marine Ecology Progress Series, 489, 107-123. http://dx.doi.org/10.3354/meps10424

[64] Hernández-Pacheco, R., Hernández-Delgado, E.A. and Sabat, A.M. (2011) Demographics of Bleaching in the Caribbean Reef-Building Coral Montastraea annularis. Ecosphere, 2, 1-13. http://dx.doi.org/10.1890/ES10-00065.1

[65] Hoegh-Guldberg, O., Mumby, P.J., Hooten, A.J., Steneck, R.S., Greenfield, P., Gomez, E., Harvell, C.D., Sale, P.F., Edwards, A.J., Caldeira, K., Knowlton, N., Eakin, C.M., Iglesias-Prieto, R., Muthiga, N., Bradbury, R.H., Dubi, A. and Hatziolos, M.E. (2007) Coral Reefs Under Rapid Climate Change and Ocean Acidification. Science, 318, 1737-1742. http://dx.doi.org/10.1126/science.1152509

[66] Veron, J.E.N., Hoegh-Guldberg, O., Lenton, T.M., Lough, J.M., Obura, D.O., Pearce-Kelly, P., Sheppard, C.R.C., Spalding, M., Stafford-Smith, M.G. and Rogers, A.D. (2009) The Coral Reef Crisis: The Critical Importance of $<350$ ppm $\mathrm{CO}_{2}$. Marine Pollution Bulletin, 58, 1428-1436. http://dx.doi.org/10.1016/j.marpolbul.2009.09.009

[67] Hoegh-Guldberg, O. and Bruno, J.F. (2010) The Impact of Climate Change on the World's Marine Ecosystems. Science, 328, 1523-1528. http://dx.doi.org/10.1126/science.1189930

[68] Hoegh-Guldberg, O. (2011) Coral Reef Ecosystems and Anthropogenic Climate Change. Regional Environmental Change, 11, 215-227. http://dx.doi.org/10.1007/s10113-010-0189-2

[69] Hernández-Delgado, E.A., Ramos-Scharrón, C.E., Guerrero, C., Lucking, M.A., Laureano, R., Méndez-Lázaro, P.A. and Meléndez-Díaz, J.O. (2012) Long-Term Impacts of Tourism and Urban Development in Tropical Coastal Habitats in a Changing Climate: Lessons Learned from Puerto Rico. In: Kasimoglu, M., Ed., Visions from Global Tourism Industry-Creating and Sustaining Competitive Strategies, InTech Publications, 357-398. http://www.intechopen.com/books/visions-for-global-tourism-industry-creating-and-sustaining-competitive-strategies/l ong-term-impacts-of-non-sustainable-tourism-and-urban-development-in-tropical-coastal-habitats-in-a

[70] Wilson, S.K., Graham, N.A., Fisher, R., Robinson, J., Nash, K., Chong-Seng, K., Polunin, N.V.C., Aumeeruddy, R. and Quatre, R. (2012) Effect of Macroalgal Expansion and Marine Protected Areas on Coral Recovery Following a Climatic Disturbance. Conservation Biology, 26, 995-1004. http://dx.doi.org/10.1111/j.1523-1739.2012.01926.x

[71] Coelho, V.R. and Manfrino, C. (2007) Coral Community Decline at a Remote Caribbean Island: Marine No-Take Reserves Are Not Enough. Aquatic Conservation: Marine and Freshwater Ecosystems, 17, 666-685. http://dx.doi.org/10.1002/aqc.822 
[72] Baums, I.B., Hugues, C.R. and Hellberg, R.E. (2005) Mendelian Microsatellite Loci for the Caribbean Coral Acropora palmata. Marine Ecology Progress Series, 288, 115-127. http://dx.doi.org/10.3354/meps288115

[73] Baums, I.B., Miller, M.W. and Hellberg, R.E. (2005) Regionally Isolated Populations of an Imperiled Caribbean Coral, Acropora palmata. Molecular Ecology, 14, 1377-1390. http://dx.doi.org/10.1111/j.1365-294X.2005.02489.x

[74] Baums, I.B., Miller, M.W. and Hellberg, R.E. (2006) Geographic Variation in Clonal Structure in a Reef Building Caribbean Coral, Acropora palmata. Ecological Monographs, 76, 503-519. http://dx.doi.org/10.1890/0012-9615(2006)076[0503:GVICSI]2.0.CO;2

[75] Baums, I.B., Paris, C.B. and Chérubin, L.M. (2006) A Bio-Oceanographic Filter to Larval Dispersal in a Reef-Building Coral. Limnology and Oceanography, 51, 1969-1981. http://dx.doi.org/10.4319/lo.2006.51.5.1969

[76] Peakall, R.O.D. and Smouse, P.E. (2006) GENALEX 6: Genetic Analysis in Excel. Population Genetic Software for Teaching and Research. Molecular Ecology Notes, 6, 288-295. http://dx.doi.org/10.1111/j.1471-8286.2005.01155.x

[77] Clarke, K.R. and Warwick, R.M. (2001) Change in Marine Communities: An Approach to Statistical Analysis and Interpretation. 2nd Edition, PRIMER-E, Ltd., Plymouth.

[78] Anderson, M.J., Gorley, R.N. and Clarke, K.R. (2008) PERMANOVA + for PRIMER: Guide to Software and Statistical Methods. PRIMER-E, Plymouth.

[79] Delissio, L. (2008) Analysis of Rainfall Data from the Island of Culebra, Puerto Rico over a Period Spanning 1907-2007 in Light of Climate Change Predictions. A Report for US Fish \& Wildlife Service, Boquerón, 1-4.

[80] Mège, P., Schizas, N.V., García-Reyes, J. and Hrbek, T. (2014) Genetic Seascape of the Threatened Caribbean Elkhorn Coral, Acropora palmate, on the Puerto Rico Shelf. Marine Ecology, 2014, 1-15.

[81] Palumbi, S.R. (2003) Population Genetics, Demographic Connectivity and the Design of Marine Reserves. Ecological Applications, 13, S146-S158. http://dx.doi.org/10.1890/1051-0761(2003)013[0146:PGDCAT]2.0.CO;2

[82] Vollmer, S.V. and Palumbi, S.R. (2004) Testing the Utility of Internally Transcribed Spacer Sequences in Coral Phylogenetics. Molecular Ecology, 13, 2763-2772. http://dx.doi.org/10.1111/j.1365-294X.2004.02265.x

[83] Van Oppen, M.J.H. and Gates, R.D. (2006) Conservation Genetics and the Resilience of Reef-Building Corals. Molecular Ecology, 15, 3863-3883. http://dx.doi.org/10.1111/j.1365-294X.2006.03026.x

[84] Vollmer, S.V. and Palumbi, S.R. (2007) Restricted Gene Flow in the Caribbean Staghorn Coral Acropora cervicornis: Implications for the Recovery of Endangered Reefs. Journal of Heredity, 98, 40-50. http://dx.doi.org/10.1093/jhered/esl057

[85] Hemond, E.M. and Vollmer, S.V. (2010) Genetic Diversity and Connectivity in the Threatened Staghorn Coral (Acropora cervicornis) in Florida. PloS ONE, 5, e8652. http://dx.doi.org/10.1371/journal.pone.0008652

[86] Palumbi, S.R., Vollmer, S., Romano, S., Oliver, T. and Ladner, J. (2012) The Role of Genes in Understanding the Evolutionary Ecology of Reef Building Corals. Evolutionary Ecology, 26, 317-335. http://dx.doi.org/10.1007/s10682-011-9517-3

[87] Meehl, G.A., Zwiers, F., Evans, J., Knutson, T., Mearns, L. and Whetton, P. (2000) Trends in Extreme Weather and Climate Events: Issues Related to Modeling Extremes in Projections of Future Climate Change. Bulletin of the American Meteorological Society, 81, 427-436. http://dx.doi.org/10.1175/1520-0477(2000)081<0427:TIEWAC>2.3.CO;2

[88] Frich, P., Alexander, L.V., Della-Marta, P., Gleason, B., Haylock, M., Klein-Tank, A.M. and Peterson, T. (2002) Observed Coherent Changes in Climatic Extremes during the Second Half of the Twentieth Century. Climate Research, 19, 193-212. http://dx.doi.org/10.3354/cr019193

[89] Peterson, T.C., Taylor, M.A., Demeritte, R., Duncombe, D.L., Burton, S., Thompson, F., Porter, A., Mercedes, M., Villegas, E., Semexant-Fils, R., Klein-Tank, A., Martis, A., Warner, R., Joyette, A., Mills, W., Alexander, L. and Gleason, B. (2002) Recent Changes in Climate Extremes in the Caribbean Region. Journal of Geophysical Research, 107, ACL 16-1-ACL 16-9. http://dx.doi.org/10.1029/2002JD002251

[90] Giannini, A., Kushnir, Y. and Cane, M.A. (2000) Interannual Variability of Caribbean Rainfall, ENSO and the Atlantic Ocean. Journal of Climate, 13, 297-311. http://dx.doi.org/10.1175/1520-0442(2000)013<0297:IVOCRE>2.0.CO;2

[91] Enfield, D.B. and Mayer, D.A. (1997) Tropical Atlantic Sea Surface Temperature Variability and Its Relation to El Niño-Southern Oscillation. Journal of Geophysical Research: Oceans (1978-2012), 102, 929-945. http://dx.doi.org/10.1029/96JC03296

[92] Emanuel, K. (2005) Increasing Destructiveness of Tropical Cyclones over the Past 30 Years. Nature, 436, $686-688$. http://dx.doi.org/10.1038/nature03906

[93] Elsner, J.B. (2006) Evidence in Support of the Climate Change-Atlantic Hurricane Hypothesis. Geophysical Research Letters, 33, Article ID: L16705. http://dx.doi.org/10.1029/2006GL026869 
[94] Mann, M.E. and Emanuel, K.A. (2006) Atlantic Hurricane Trends Linked to Climate Change. EOS, Transactions American Geophysical Union, 87, 233-241. http://dx.doi.org/10.1029/2006EO240001

[95] Easterling, D.R., Evans, J.L., Groisman, P.Y., Karl, T.R., Kunkel, K.E. and Ambenje, P. (2000) Observed Variability and Trends in Extreme Climate Events: A Brief Review. Bulletin of the American Meteorological Society, 81, 417-425. http://dx.doi.org/10.1175/1520-0477(2000)081<0417:OVATIE>2.3.CO;2

[96] Eakin, C.M., Morgan, J.A., Smith, T.B., Liu, G., Alvarez-Filip, L., Baca, B., Bouchon, C., Brandt, M., Bruckner, A., Cameron, A., Carr, L., Chiappone, M., James, M., Crabbe, C., Day, O., de la Guardia-Llanso, E., DiResta, D., Gilliam, D., Ginsburg, R., Gore, S., Guzmán, H., Hernández-Delgado, E.A., Husain, E., Jeffrey, C., Jones, R., Jordán-Dahlgren, E., Kramer, P., Lang, J., Lirman, D., Mallela, J., Manfrino, C., Maréchal, J.P., Mihaly, J., Miller, J., Mueller, E., Muller, E., Noordeloos, M., Oxenford, H., Ponce-Taylor, D., Quinn, N., Ritchie, K., Rodríguez, S., Rodríguez-Ramírez, A., Romano, S., Samhouri, J., Schmahl, G., Steiner, S., Taylor, M., Walsh, S., Weil, E. and Williams, E. (2010) Caribbean Corals in Crisis: Record Thermal Stress, Bleaching and Mortality in 2005. PLoS ONE, 5, e13969. http://dx.doi.org/10.1371/journal.pone.0013969

[97] Easterling, D.R., Meehl, G.A., Parmesan, C., Changnon, S.A., Karl, T.R. and Mearns, L.O. (2000) Climate Extremes: Observations, Modeling and Impacts. Science, 289, 2068-2074. http://dx.doi.org/10.1126/science.289.5487.2068

[98] Worrall, F., Reed, M., Warburton, J. and Burt, T. (2003) Carbon Budget for a British Upland Peat Catchment. Science of the Total Environment, 312, 133-146. http://dx.doi.org/10.1016/S0048-9697(03)00226-2

[99] Johnson, M.S., Lehmann, J., Couto, E.G., Filho, J.P.N. and Riha, S.J. (2006) DOC and DIC in Flowpaths of Amazonian Headwater Catchments with Hydrologically Contrasting Soils. Biogeochemistry, 81, 45-57. http://dx.doi.org/10.1007/s10533-006-9029-3

[100] Liu, Z., Dreybrodt, W. and Wang, H. (2010) A New Direction in Effective Accounting for the Atmospheric $\mathrm{CO}_{2}$ Budget: Considering the Combined Action of Carbonate Dissolution, the Global Water Cycle and Photosynthetic Uptake of DIC by Aquatic Organisms. Earth-Science Reviews, 99, 162-172. http://dx.doi.org/10.1016/j.earscirev.2010.03.001

[101] Cai, W.J., Hu, X., Huang, W.J., Murrell, M.C., Lehrter, J.C., Lohrenz, S.E., Chou, W.C., Zhai, W., Hollibaugh, J.T., Wang, Y., Zhao, P., Guo, X., Gundersen, K., Dai, M. and Gong, G.C. (2011) Acidification of Subsurface Coastal Waters Enhanced by Eutrophication. Nature Geoscience, 4, 766-770. http://dx.doi.org/10.1038/ngeo1297

[102] Hernández-Delgado, E.A. Medina, J., Ortiz, V., Mas, M., Marrero, P.A., Mattei, H. and Norat-Ramírez, J. (2009) Biological Characterization of Shallow-Water Coral Reef Communities across a Water Quality Gradient within the Luis Peña Channel Natural Reserve, Culebra Island, Puerto Rico. Final Technical Report, Department of Environmental Health, Public Health Graduate School, University of Puerto Rico-Medical Sciences Campus and Department of Natural and Environmental Resources, San Juan, 77 p.

[103] Govender, Y., Cuevas, E., Sternberg, L.D.S. and Jury, M.R. (2013) Temporal Variation in Stable Isotopic Composition of Rainfall and Groundwater in a Tropical Dry Forest in the Northeastern Caribbean. Earth Interactions, 17, 1-20. http://dx.doi.org/10.1175/2013EI000534.1

[104] Zanchetta, G., Drysdale, R.N., Hellstrom, J.C., Fallick, A.E., Isola, I., Gagan, M.K. and Pareschi, M.T. (2007) Enhanced Rainfall in the Western Mediterranean during Deposition of Sapropel S1: Stalagmite Evidence from Corchia Cave (Central Italy). Quaternary Science Reviews, 26, 279-286. http://dx.doi.org/10.1016/j.quascirev.2006.12.003

[105] Nowlis, J.S., Roberts, C.M., Smith, A.H. and Siirila, E. (1997) Human-Enhanced Impacts of a Tropical Storm on Nearshore Coral Reefs. AMBIO, 26, 515-521.

[106] Kaczmarsky, L.T., Draud, M. and Williams, E.H. (2005) Is There a Relationship between Proximity to Sewage Effluent and the Prevalence of Coral Disease. Caribbean Journal Science, 41, 124-137.

[107] Voss, J.D. and Richardson, L.L. (2006) Nutrient Enrichment Enhances Black Band Disease Progression in Corals. Coral Reefs, 25, 569-576. http://dx.doi.org/10.1007/s00338-006-0131-8

[108] Quinn, N.J. and Kojis, B.L. (2006) Evaluating the Potential of Natural Reproduction and Artificial Techniques to Increase Acropora cervicornis Populations at Discovery Bay, Jamaica. Revista de Biología Tropical, 54, 105-116.

[109] Herlan, J. and Lirman, D. (2010) Development of a Coral Nursery Program for the Threatened Coral Acropora cervicornis in Florida. Proceedings of the 11th International Coral Reef Symposium, Session No. 24, 1244-1247.

[110] Lirman, D., Thyberg, T., Herlan, J., Hill, C., Young-Lahiff, C., Schopmeyer, S., Huntington, B., Santos, R. and Drury, C. (2010) Propagation of the Threatened Staghorn Coral Acropora cervicornis: Methods to Minimize the Impacts of Fragment Collection and Maximize Production. Coral Reefs, 29, 729-735. http://dx.doi.org/10.1007/s00338-010-0621-6

[111] Gladfelter, E.H., Monahan, R.K. and Gladfelter, W.B. (1978) Growth Rates of Five Reef-Building Corals in the Northeastern Caribbean. Bulletin of Marine Science, 28, 728-734.

[112] Gladfelter, E.H. (1984) Skeletal Development in Acropora cervicornis. III. A Comparison of Monthly Rates of Linear 
Extension and Calcium Carbonate Accretion Measured over a Year. Coral Reefs, 3, 51-57. http://dx.doi.org/10.1007/BF00306140

[113] Vaughan, T.W. (1915) The Geological Significance of the Growth-Rate of the Floridian and Bahaman Shoal-Water Corals. Journal of the Washington Academy of Science, 5, 591-600.

[114] Shinn, E.A. (1966) Coral Growth-Rate, an Environmental Indicator. Journal of Paleontology, 40, $233-240$.

[115] Glynn, P.W. (1973) Aspects of the Ecology of Coral Reefs in the Western Atlantic Region. In: Jones, O.A. and Endean, R., Eds., Biology and Geology of Coral Reefs, Vol. 2: Biology 1, Academic Press, New York, 271-324.

[116] Lewis, J.B., Axelsen, F., Goodbody, I., Page, C. and Chislett, G. (1968) Comparative Growth Rates of Some Reef Corals in the Caribbean (No. MS-10). McGill University, Montreal, Marine Sciences Centre.

[117] Tunnicliffe, V. (1983) Caribbean Staghorn Coral Populations: Pre-Hurricane Allen Conditions in Discovery Bay, Jamaica. Bulletin of Marine Science, 33, 132-151.

[118] García-Urueña, R.P. (2004) Dinámica de Crecimiento de Tres Especies de Coral en Relación a las Propiedades Opticas del Agua. Ph.D. Dissertation, Department of Marine Sciences, University of Puerto Rico, Mayagüez, 139 p.

[119] Bowden-Kerby, A. (2001) Low-Tech Coral Reef Restoration Methods Modeled after Natural Fragmentation Processes. Bulletin of Marine Science, 69, 915-931.

[120] Wooldridge, S.A. (2014) Assessing Coral Health and Resilience in a Warming Ocean: Why Looks Can Be Deceptive. Bioessays, 36, 1-9.

[121] Hernández-Delgado, E.A., Rosado-Matías, B.J. and Sabat, A.M. (2006) Management Failures and Coral Decline Threaten Fish Functional Groups Recovery Patterns in the Luis Peña Channel No-Take Natural Reserve, Culebra Island, PR. Proceedings of the Gulf and Caribbean Fisheries Institute, 57, 577-605.

[122] Roberts, C.M. (1995) Rapid Build-Up of Fish Biomass in a Caribbean Marine Reserve. Conservation Biology, 9, 815826. http://dx.doi.org/10.1046/j.1523-1739.1995.09040815.x

[123] Aronson, R.B. and Precht, W.F. (2006) Conservation, Precaution and Caribbean Reefs. Coral Reefs, 25, 441-450. http://dx.doi.org/10.1007/s00338-006-0122-9

[124] Mumby, P.J. and Hastings, A. (2008) The Impact of Ecosystem Connectivity on Coral Reef Resilience. Journal of Applied Ecology, 45, 854-862. http://dx.doi.org/10.1111/j.1365-2664.2008.01459.x

[125] Mumby, P.J. and Harborne, A.R. (2010) Marine Reserves Enhance the Recovery of Corals on Caribbean Reefs. PLoS ONE, 5, e8657. http://dx.doi.org/10.1371/journal.pone.0008657

[126] Roff, G. and Mumby, P.J. (2012) Global Disparity in the Resilience of Coral Reefs. Trends in Ecology \& Evolution, 27, 404-413. http://dx.doi.org/10.1016/j.tree.2012.04.007

[127] Bellwood, D.R., Hughes, T.P., Folke, C. and Nyström, M. (2004) Confronting the Coral Reef Crisis. Nature, 429, 827833. http://dx.doi.org/10.1038/nature02691

[128] Miller, J., Muller, E., Rogers, C., Waara, R., Atkinson, A., Whelan, K.R.T., Patterson, M. and Witcher, B. (2009) Coral Disease Following Massive Bleaching in 2005 Causes 60\% Decline in Coral Cover on Reefs in the US Virgin Islands. Coral Reefs, 28, 925-937. http://dx.doi.org/10.1007/s00338-009-0531-7

[129] Hughes, T.P., Baird, A.H., Bellwood, D.R., Card, M., Connolly, S.R., Folke, C., Grosberg, R., Hoegh-Guldberg, O., Jackson, J.B.C., Kleypas, J., Lough, J.M., Marshall, P., Nyström, M., Palumbi, S.R., Pandolfi, J.M., Rosen, B. and Roughgarden, J. (2003) Climate Change, Human Impacts and the Resilience of Coral Reefs. Science, 301, 929-933. http://dx.doi.org/10.1126/science.1085046

[130] Ramos-Scharrón, C.E., Amador, J.M. and Hernández-Delgado, E.A. (2012) An Interdisciplinary Erosion Mitigation Approach for Coral Reef Protection-A Case Study from the Eastern Caribbean. In: Cruzado, A., Ed., Marine Ecosystems, InTech Publications, 127-160. http://www.intechopen.com/articles/show/title/an-interdisciplinary-erosion-mitigation-approach-for-coral-reef-protecti on-a-case-study-from-the-eas

[131] Sturm, P., Viqueira-Ríos, R., Meyer-Comas, L., Hernández-Delgado, E.A., González-Ramos, C., Montañez-Acuña, A. and Otaño-Cruz, A. (2014) Culebra Community Watershed Action Plan for Water Quality and Coral Reefs. Technical Report Submitted to NOAA, Silver Spring, $76 \mathrm{p}$.

[132] Hughes, T.P., Bellwood, D.R., Folke, C., Steneck, R.S. and Wilson, J. (2005) New Paradigms for Supporting the Resilience of Marine Ecosystems. Trends in Ecology and Evolution, 20, 380-386. http://dx.doi.org/10.1016/j.tree.2005.03.022

[133] Bowden-Kerby, A. and Carne, L. (2012) Thermal Tolerance as a Factor in Caribbean Acropora Restoration. Proceedings of the 12th International Coral Reef Symposium, 1-5.

[134] Dixson, D.L., Abrego, D. and Hay, M.E. (2014) Chemically Mediated Behavior of Recruiting Corals and Fishes: A Tipping Point that May Limit Reef Recovery. Science, 345, 892-897. http://dx.doi.org/10.1126/science.1255057 
E. A. Hernández-Delgado et al.

[135] Pandolfi, J.M., Jackson, J.B.C., Baron, N., Bradbury, R.H., Guzman, H.M., Hughes, T.P., Kappel, C.V., Micheli, F., Ogden, J.C., Possingham, H.P. and Sala, E. (2005) Are US Coral Reefs on the Slippery Slope to Slime? Science, 307, 1725-1726. http://dx.doi.org/10.1126/science.1104258 
Scientific Research Publishing (SCIRP) is one of the largest Open Access journal publishers. It is currently publishing more than 200 open access, online, peer-reviewed journals covering a wide range of academic disciplines. SCIRP serves the worldwide academic communities and contributes to the progress and application of science with its publication.

Other selected journals from SCIRP are listed as below. Submit your manuscript to us via either submit@scirp.org or Online Submission Portal.
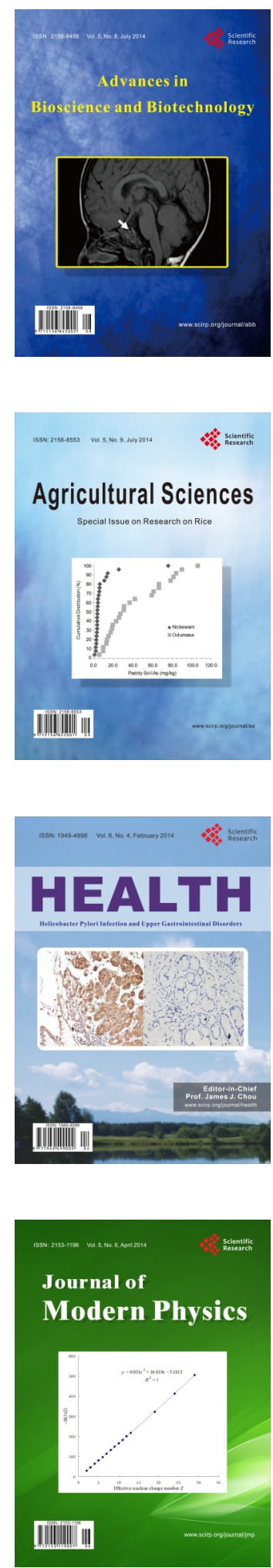
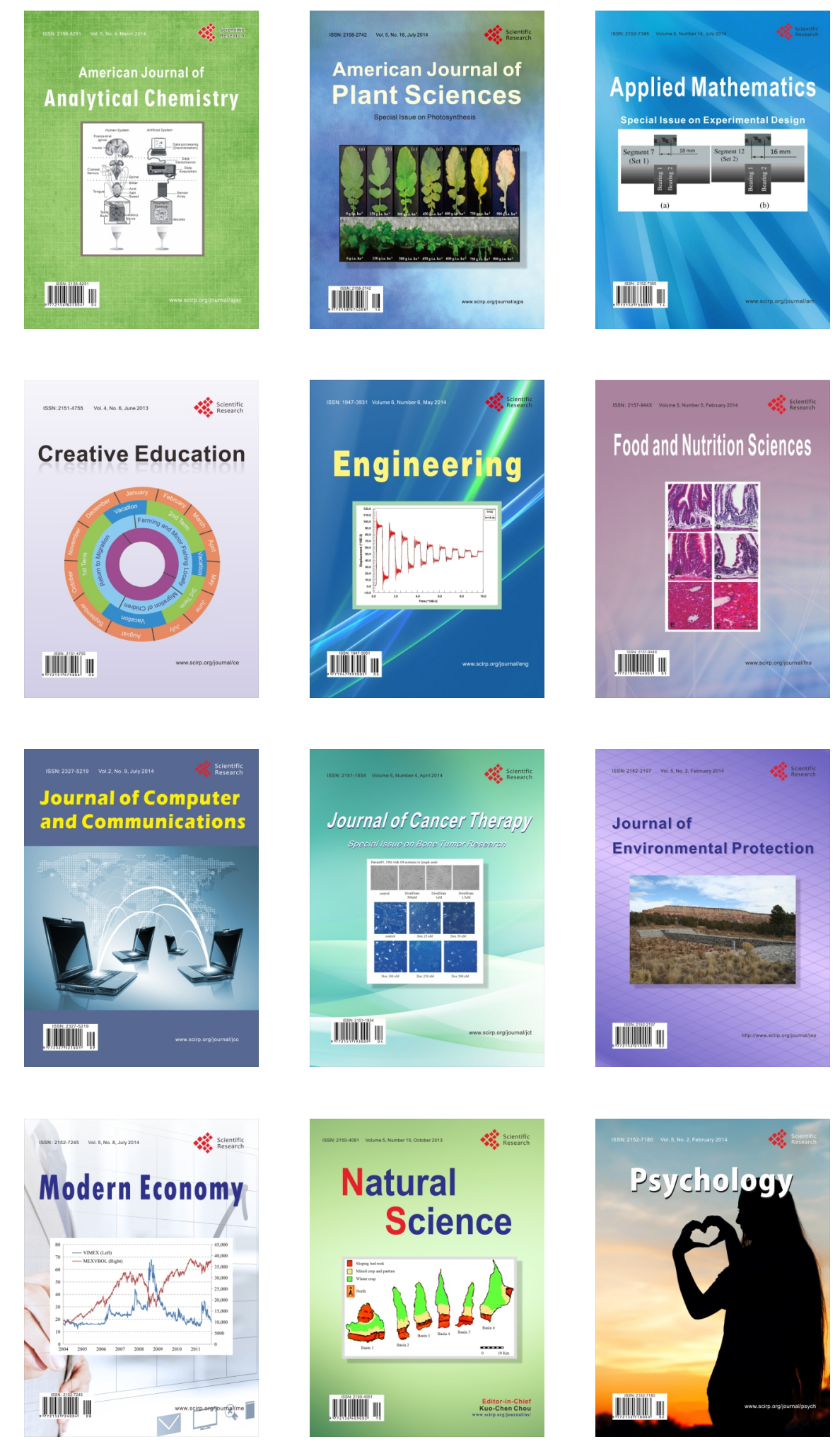